\title{
Biogeochemical Mobility of Contaminants from a Replica Radioactive Waste Trench in Response to Rainfall-induced Redox Oscillations
}

Andrew S. Kinsela, Mark W. Bligh, Xabier Vázquez-Campos, Yingying Sun, Marc R. Wilkins, M. Josick Comarmond, Brett Rowling, Timothy E. Payne and T. David Waite

(18 pages)

Contents

SECTION S1 - ADDITIONAL FIELD SITE INFORMATION ........................................................................

SECTION S2 - ADDITIONAL METHODOLOGY DETAILS .......................................................................

SECTION S3 - ADDITIONAL FIELD AND CHEMICAL PARAMETERS........................................................6

SECTION S4 - ADDITIONAL MICROBIOLOGY PARAMETERS...................................................................15

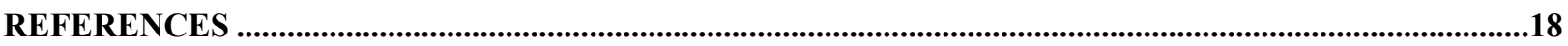

\section{SECTION S1 - Additional Field Site Information}

The replica trench was excavated in July 2018 to the specified dimensions of $3.0 \mathrm{~m}$ long, $0.6 \mathrm{~m}$ wide and $3.0 \mathrm{~m}$ deep (all of which were $\pm 0.05 \mathrm{~m}$ upon completion). The dimensions of the legacy waste trenches have been reported to be nominally $25 \times 0.6 \times 3 \mathrm{~m}$, with shorter length trenches also recorded (Payne 2012). The lithology encountered during the excavation was as has been described in more detail elsewhere. ${ }^{1,2}$ Briefly though, an organic topsoil (to $0.2 \mathrm{~m}$ b.g.1.) overlies a highly weathered clay layer (to $0.95 \mathrm{~m}$ b.g.l.) rich in iron oxides. Beneath this, a transition to parent shale material occurs to a depth of $2.0 \mathrm{~m}$ b.g.l. and continues to below the trench base (at $3.0 \mathrm{~m}$ b.g.1.).

The replica trench was filled with materials that were considered to be representative of major chemical and physical components of the legacy trenches, excluding any radioactive or harmful contaminants. The historical disposal and photographic records at LFLS show that certain container materials were commonly disposed of in the majority of trenches. ${ }^{3}$ As such, two of these non-hazardous materials (steel drums and cardboard) were used in the replica trench. Aged mulch was added to the trench to stimulate soil microbial processes as well as safely replicate the presence of co-disposed organic components. A summary of these materials, as well as the reasoning behind their inclusion, approximate quantities added and volumetric proportions are provided in Table S1.1. 
Table S1.1: Materials used to fill the bottom two metres of the Chemistry Trench filling

\begin{tabular}{|c|c|c|c|}
\hline Material & Role / Representation & $\begin{array}{l}\text { Approx } \\
\text { quantity }\end{array}$ & $\begin{array}{l}\text { Approx. } \\
\text { volume }\end{array}$ \\
\hline Aged mulch & $\begin{array}{ll}\text { - } & \text { Primarily as a source of carbon } \\
\text { - } & \text { Nutrients }(\mathrm{N}, \mathrm{P}) \text { for microbial growth } \\
\text { - } & \text { Soil microorganisms }\end{array}$ & $1 \mathrm{~m}^{3}$ & $30 \%$ \\
\hline River pebbles $(40 \mathrm{~mm})$ & $\begin{array}{l}\text { - } \quad \text { Structural support } \\
\text { - } \quad \text { Enhance porosity }\end{array}$ & $1 \mathrm{~m}^{3}$ & $30 \%$ \\
\hline Cardboard (shredded) & $\begin{array}{l}\text { - Non-toxic component known to have been placed in the } \\
\text { legacy trenches } \\
\text { - } \quad \text { Carbon source }\end{array}$ & $30 \mathrm{~kg}$ & $5 \%$ \\
\hline Topsoil & $\begin{array}{ll}\text { - } & \text { Structural purposes (smaller fill material) } \\
\text { - } & \text { Soil microorganisms }\end{array}$ & $0.5 \mathrm{~m}^{3}$ & $15 \%$ \\
\hline $\begin{array}{l}\text { Weathered shale from } \\
\text { trench excavation }\end{array}$ & $\begin{array}{ll}\text { - } & \text { Structural purposes } \\
\text { - } & \text { Likely material used in legacy trench infilling }\end{array}$ & $0.5 \mathrm{~m}^{3}$ & $15 \%$ \\
\hline $\begin{array}{l}\text { Red clay from trench } \\
\text { excavation }\end{array}$ & $\begin{array}{ll}\text { - } & \text { Structural purposes } \\
\text { - } & \text { Likely material used in legacy trenches }\end{array}$ & $0.2 \mathrm{~m}^{3}$ & $5 \%$ \\
\hline $\begin{array}{l}\text { Steel drum (200L, open } \\
\text { lid) }\end{array}$ & $\begin{array}{l}\text { - } \quad \text { Non-toxic component known to be in the legacy } \\
\text { trenches } \\
\text { - } \quad \text { Continuous reservoir of saturated material } \\
\text { - } \quad \text { Source of iron (long term supply) }\end{array}$ & 1 unit & Neg. \\
\hline Steel wool & $\begin{array}{l}\text { - Source of immediate to medium-term supply of iron } \\
\text { (corrosion products) }\end{array}$ & $1.5 \mathrm{~kg}$ & Neg. \\
\hline $\begin{array}{l}\text { Slotted PVC pipe } \\
(20 \mathrm{~mm} \times 1 \mathrm{~m} \text { lengths) }\end{array}$ & - Hydraulic purposes to ensure longitudinal connectivity & 10 units & Neg. \\
\hline
\end{tabular}

These simulated waste materials were added to the trench in repeated small batches to ensure the infill product was well-mixed and not stratified. A multi-level piezometer, depth logging port and contaminant/tracer introduction port were positioned in the trench prior to the addition of the simulated waste materials. These materials occupied the bottom two meters of the trench, with the upper $1 \mathrm{~m}$ overlaying this comprised of re-used clay and top soils as per that used in the legacy waste trenches. ${ }^{3}$ It is important to recognise that the entire contents of the trench were composed of materials having angular / geometric dimensions (fractured shale, larger clay fragments, woody mulch, pebbles and cardboard boxes), which would only have been partially infilled by finer material (e.g. topsoil). The specific intention underlying this process was to replicate the horizontal and vertical void spaces which are inherent to legacy waste trenches. Schematics depicting the trench dimensions and details of the multi-level piezometer are shown in Figure S1.1. 

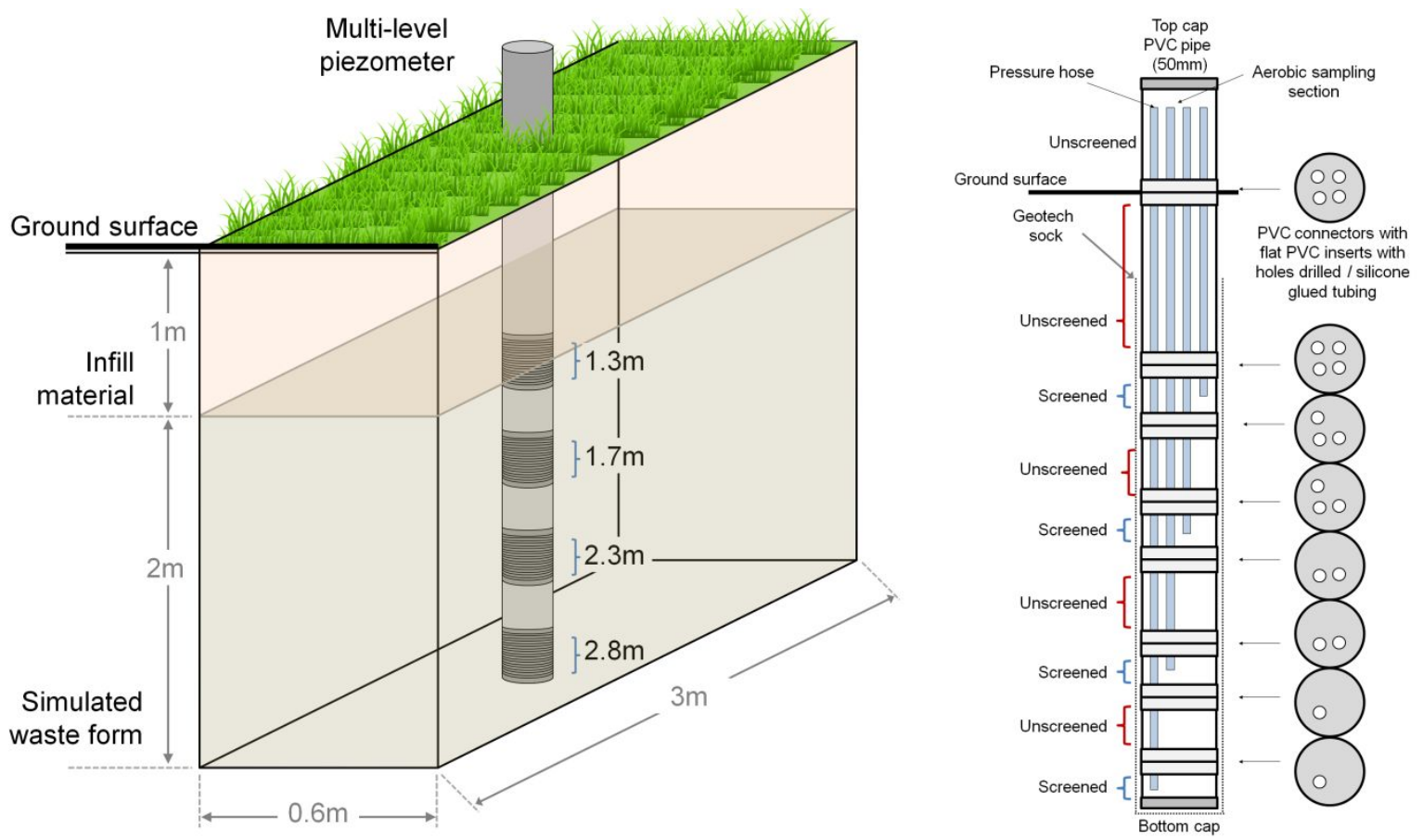

Figure S1.1: (Idealised) schematic of the chemistry trench showing spatial dimensions and multi-piezometer sampling depths (left). Schematic of the multi-level piezometer buried into the trench (right). Not to scale.

The multi-level piezometer was constructed to enable the collection of water samples from four discrete depths $(1.3,1.8,2.3$ and $2.8 \mathrm{~m}$ b.g.l.) within the replica trench. Its fabrication involved connecting sections of screened and unscreened PVC with an internal diameter $(\varnothing)$ of $50 \mathrm{~mm}$, which were separated by glued PVC discs designed to minimise the collection of water from depths immediately above and below. Sample collection at each of the four depths was via individual $8 \mathrm{~mm}$ reinforced hosing pipe silicone-sealed into place, which extended above the ground surface. The piezometer was encased in $\varnothing 50 \mathrm{~mm}$ geotextile fabric composed of polyester. The overall design presented as a schematic is shown in Figure S1.1 (right).

The compounds $\mathrm{CsCl}(25 \mathrm{~g}), \mathrm{SrCl}_{2} \cdot 6 \mathrm{H}_{2} \mathrm{O}(60.6 \mathrm{~g}), \mathrm{Nd}\left(\mathrm{NO}_{3}\right)_{3} \cdot 6 \mathrm{H}_{2} \mathrm{O}(50 \mathrm{~g})$ and $\mathrm{LiBr}(100 \mathrm{~g})$ (all AR grade, Sigma Aldrich) used for simulated contaminant and tracer additions were each dissolved in 1L of MQ water. They were simultaneously added to the trench on Day 20 in single pulse like motions which would have induced some mixing and dispersion of the contaminants. The first sample point after their introduction was five days later, on Day 25.

\section{SECTION S2 - Additional Methodology Details}

ICP: Major and trace cations in filtered and unfiltered samples were preserved by the addition of $15.8 \mathrm{M}$ $\mathrm{HNO}_{3}$ (to $2 \% \mathrm{v} / \mathrm{v}$ ) shortly after collection. Fe(III) total concentrations presented in Figure 2A were measured from unfiltered and acidified samples. Additional $\mathrm{HNO}_{3}$ (to $5 \% \mathrm{v} / \mathrm{v}$ ) was added to unfiltered samples to dissolve amorphous and weakly crystalline solid phases. Samples were variously diluted with $2 \% \mathrm{HNO}_{3}$ prior to analysis. Major cations were measured by ICP-OES (Agilent 720), using a OneNeb nebuliser under standard operating conditions. Instrument drift was minimised by frequent recalibration using a NIST-derived high-purity multi-element standard (IV, Merck Millipore). Trace cations were 
measured by ICP-MS (Agilent 7700x), again using a standard setup with the helium collision cell (3.5 $\mathrm{mL} / \mathrm{min}$ ) used to remove spectral interferences. In addition to frequent recalibration, instrument drift and matrix interactions with the plasma were assessed by monitoring the recovery of an in-line internal standard containing ${ }^{45} \mathrm{Sc},{ }^{72} \mathrm{Ge},{ }^{89} \mathrm{Y}$ and ${ }^{159} \mathrm{~Tb}$. Internal standard recovery was typically 90 to $110 \%$, and samples outside the $\pm 20 \%$ range were diluted and reanalysed.

IC: Samples for anion analysis were maintained at $4{ }^{\circ} \mathrm{C}$ until analysis, which were typically performed within 3 days of collection. Chromatographic separation of anions was undertaken using a Dionex ICS3000 instrument. Samples were diluted with high-purity water immediately prior to analysis before they were injected $(25 \mu \mathrm{L})$ into an IonPac AS-18 $(4 \mathrm{~mm})$ column (+ guard column) maintained at $30^{\circ} \mathrm{C}$, with $\mathrm{KOH}(36.6 \mathrm{mM})$ used at the eluent, operating at a flow rate of $1.0 \mathrm{~mL} / \mathrm{min}$. This resulted in fast separation of the anions of interest $(10 \mathrm{~min})$. Anions were quantified by paired measurements of a NIST-traceable multi-anion solution (Dionex II; ThermoFisher Scientific).

DOC / DIC: Paired filtered samples for DOC / DIC measurements were collected in acid-washed glass vials with minimal headspace, and maintained at $4{ }^{\circ} \mathrm{C}$ prior to analysis, which was typically performed within 48 hrs of collection using a high temperature catalytic oxidation combustion analyser (TOC- $\mathrm{V}_{\mathrm{CSH}}$; Shimadzu). A solution of potassium hydrogen phthalate was prepared according to the instrument manufacturers' instructions to be used as the analytical standard. High-purity concentrated $\mathrm{HCl}$ (to $\mathrm{pH} 2$ ) was added to one replicate to remove inorganic carbon with the resultant $\mathrm{CO}_{2}$ purged using zero-grade air. DIC was calculated from the difference between the non-acidified and acidified replicates. An underestimation of DIC concentrations due to samples degassing was considered negligible. All samples were diluted with high-purity water immediately prior to analysis to ensure carbon concentrations were $<50 \mathrm{mg} / \mathrm{L}$. Analysis of multiple blank solutions indicated a reporting level of between 0.2 and $0.3 \mathrm{mg} / \mathrm{L}$ C.

Oxidant Production: The oxidant production capability of the samples was calculated from transformation of the probe compound, benzoic acid, to its product $p$-hydroxybenzoate ( $p$-HBA). Trench water samples were exposed to oxygen in the presence of benzoic acid as a means to comparatively assess the total oxidant production capacity between different time points and depths. Environmental samples were added to benzoic acid $(20 \mathrm{mM})$ and MES-buffer $(20 \mathrm{mM}$, pH 6.5$)$ containing vials with $150 \%$ headspace (by volume) and shaken in the dark for 24 hours. Vial caps were periodically opened to ensure oxygen was not depleted. To comparatively assess the oxidant production, the samples were filtered and diluted (50:50 volume) with HPLC-grade methanol at exactly $24 \mathrm{hrs}$ after their collection, prior to HPLC analysis, which was performed within 3 days of sample collection. The $p$-HBA product was quantified by HPLC (Agilent 1200) equipped with a C18 column (Zorbax Eclipse, $4.6 \times 150 \mathrm{~mm}, 5 \mu \mathrm{m}$ ). The HPLC mobile phase contained $10 \%$ acetonitrile and $90 \%$ formic acid $(1.42 \% \mathrm{w} / \mathrm{w})$, having a $\mathrm{pH}$ of 2.0 , which resulted in a retention time for $p$-HBA of 6.2 mins. Injection volume was $50 \mu \mathrm{L}$ at a rate of $1 \mathrm{~mL} / \mathrm{min}$, and the limit of detection was $0.1 \mu \mathrm{M} p$-HBA. Cumulative hydroxyl radical production was calculated using the empirical multiplication conversion factor $(\times 5.87){ }^{4}$ 
DNA Extraction and Sequencing: DNA was extracted from Sterivex filters using the DNeasy PowerSoil Kit (QIAGEN) with the following modifications made to that reported by Vázquez-Campos et al. ${ }^{5}$; i) only half of the Sterivex membrane was used for each DNA extraction, and ii) bead beating parameters were 1,800 rpm for $5 \mathrm{~min}$ on the PowerLyzer 24 Bench Top Bead-Based Homogenizer (Mo Bio).

Sequencing was performed at the Ramaciotti Centre for Genomics (UNSW, Sydney) as per the Earth Microbiome Project protocol using primers specific for the region V4 of the 16S rRNA gene: 515F-Y (515$\mathrm{FB})^{6}$ and 806RB. ${ }^{7}$ PCR products were normalised and pooled using SequalPrep ${ }^{\mathrm{TM}}$ Normalization Plate Kit (ThermoFisher) according to manufacturer's instructions. The library was purified using AMPure XP (Beckman Coulter) as per the manufacturer's instructions. Concentration and quality of the pooled library were checked with Qubit $\AA$ and the library size on an Agilent 2200 TapeStation instrument. The library pool was sequenced on the MiSeq using a MiSeq Reagent Kit v2 with a 2x250 bp run format, using default run parameters including adaptor trimming.

Raw sequencing data was processed with the OTUreporter v1.0.1-beta (bdaa45f) pipeline (https://bitbucket.org/xvazquezc/otureporter), based on mothur (v1.39.5) ${ }^{8}$. Briefly, the reads were qualityfiltered and assigned to their respective samples. Sequences were trimmed according to the MiSeq SOP (https://www.mothur.org/wiki/MiSeq_SOP). Samples with homopolymers longer than 8 bp were removed. Chimeric sequences were removed using the chimera.vsearch script included in mothur ${ }^{9}$. The sequences were aligned and classified against the SILVA reference alignment (v132, http://www.arb-

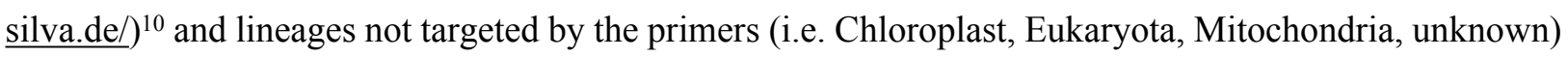
were removed. Sequences were grouped into OTUs based on $97 \%$ similarity using the OptiClust algorithm $^{11}$ and sub-sampled based on the sample with the lowest number of sequences, i.e. 54698 sequences.

Microbial community structure was examined in $\mathrm{R}$ with the phyloseq package v1.30.0. ${ }^{12}$ Ecological diversity indexes were calculated with the microbiome package v1.8.0 (https://github.com/microbiome/microbiome/).

Thermodynamic Modelling: Calculations were performed using Visual Minteq version $3.1,{ }^{13}$ using the measured aqueous components listed in Table 3.1. The 'thermo.vdb' thermodynamic database with Davies activity correction was used. DIC concentrations and $\mathrm{pH}$ values were used to calculate $\mathrm{CO}_{3}{ }^{2-}$ concentrations. The Stockholm Humic Model was used for calculations of metal-humic complexation in which default parameters were selected. 


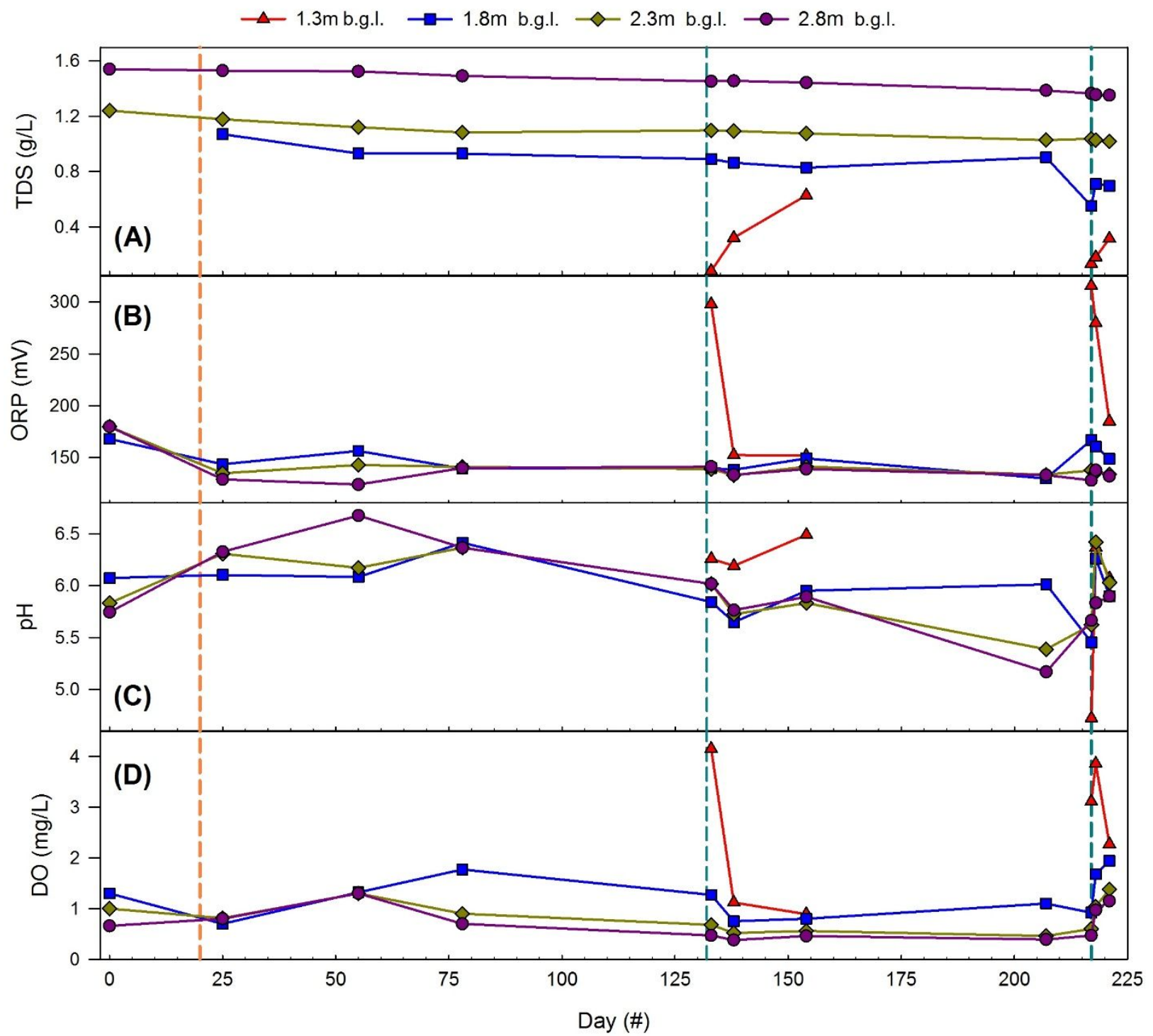

Figure S3.1: Time course measurements over the course of the field experiment depicting, (A) Total dissolved solids (TDS), (B) oxidation-reduction potential (ORP), (C) pH and (D) DO from the replica trench. Samples were collected from the multilevel piezometer at the four heights below ground level $(1.3,1.8,2.3$ and $2.8 \mathrm{~m})$ during individual sampling campaigns. The two primary redox events are marked with dashed blue vertical lines. 


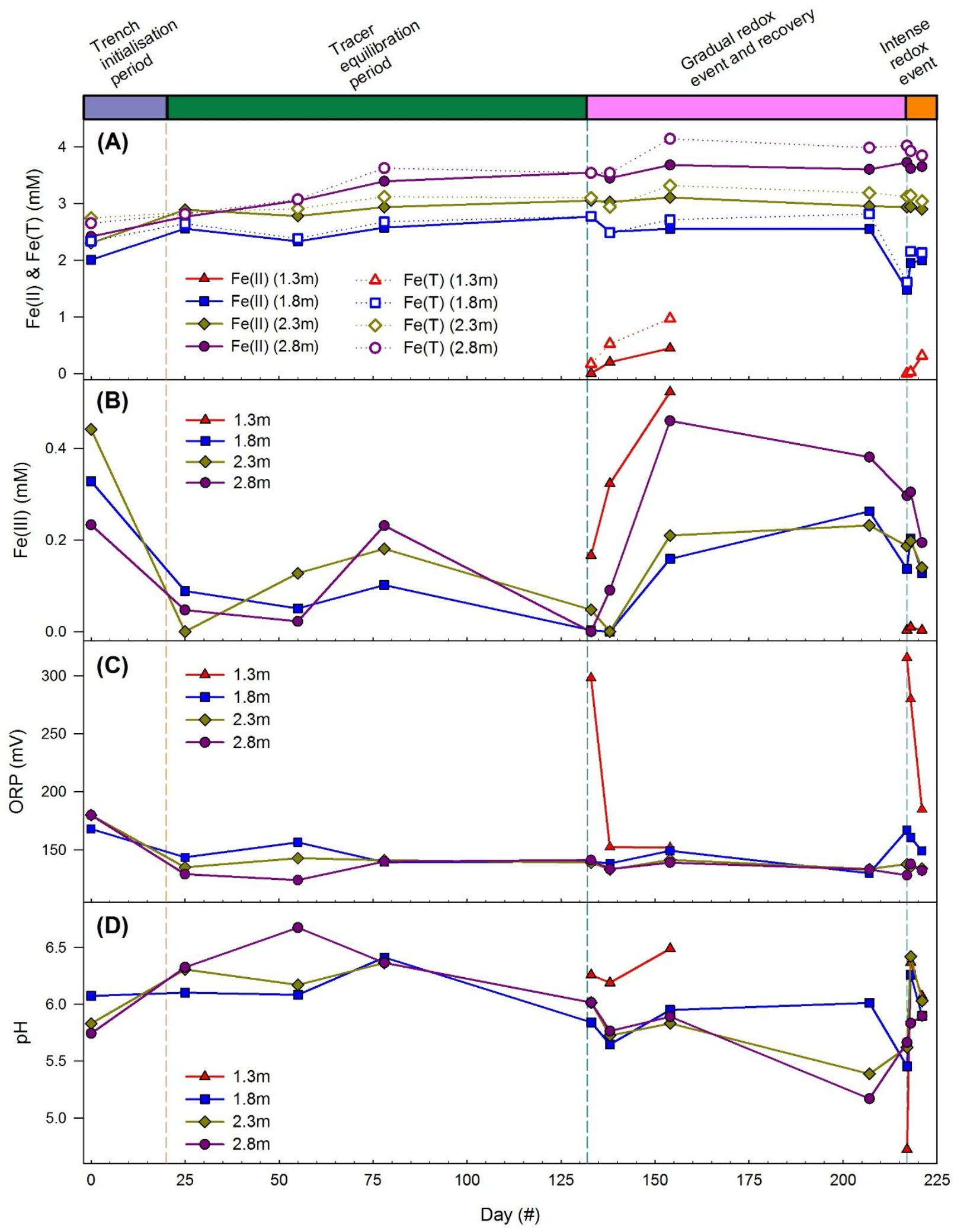

Figure S3.2: Time course measurements over the course of the field experiment depicting, (A) Fe(II) and Fe(total), (B) $\mathrm{Fe}$ (III) defined by the difference between $\mathrm{Fe}$ (total) and $\mathrm{Fe}(\mathrm{II}),(\mathrm{C})$ oxidation-reduction potential (ORP) and (D) $\mathrm{pH}$ from the replica trench. Samples were collected from the multilevel piezometer at the four heights below ground level $(1.3,1.8,2.3$ and $2.8 \mathrm{~m})$ during individual sampling campaigns. The two primary redox events are marked with dashed blue vertical lines. 


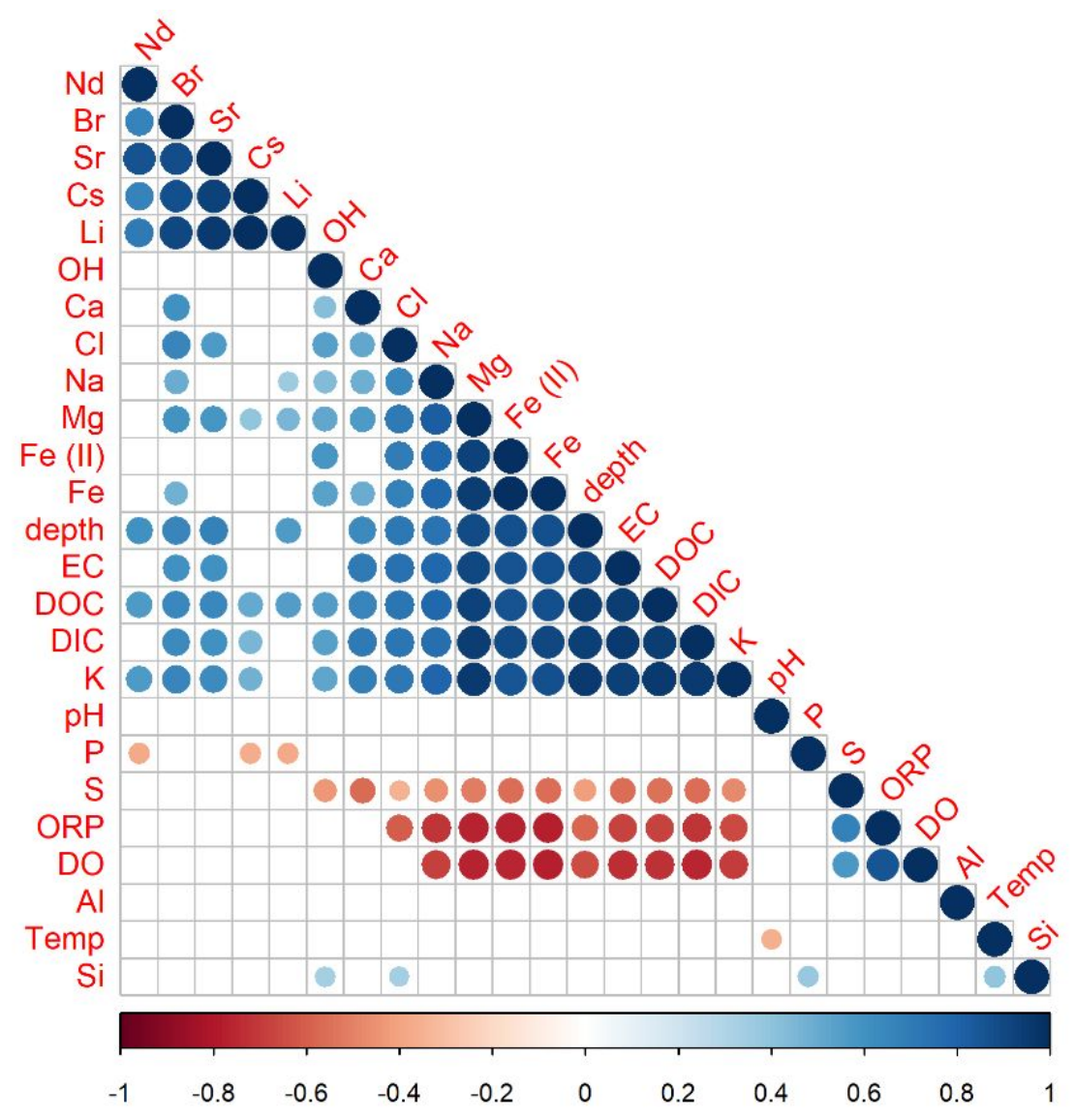

Figure S3.3: Visual representation of the Pearson's correlation between various geochemical parameters. Parameters are ordered based on hierarchical clustering, in order to group similar behaviour. The direction of the correlation is indicated by red/blue colour depicted in the scale bar, while the strength of the correlation is depicted by the circle colour intensity and size. Only significant correlation values $(p \leq 0.05)$ are shown

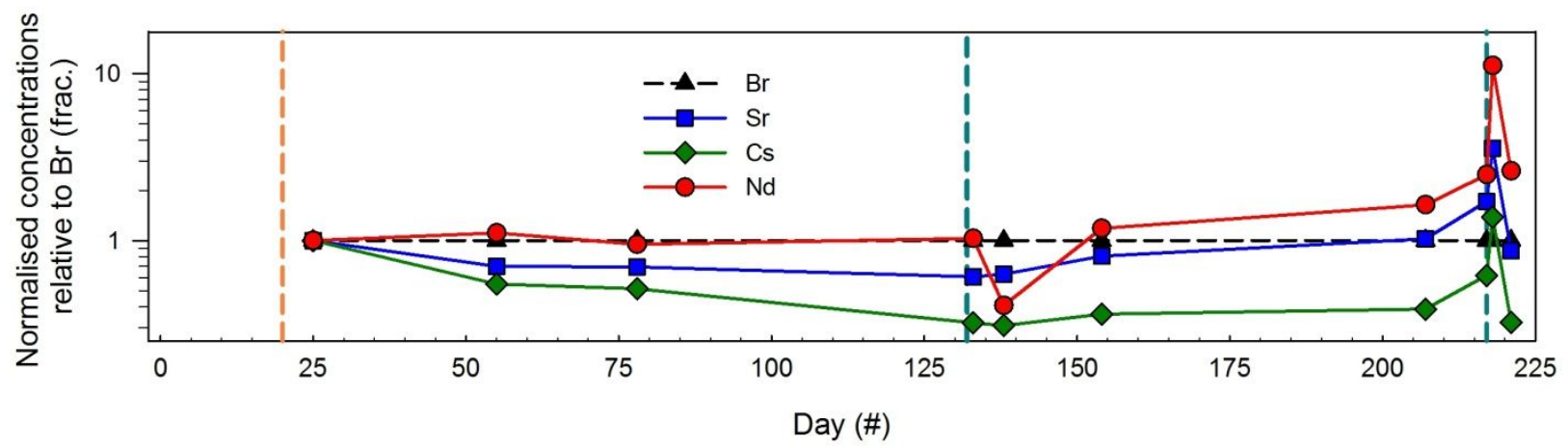

Figure S3.4: Variation in quantities of contaminants ( $\mathrm{Sr}$, Cs and $\mathrm{Nd}$ ) at depth $2.8 \mathrm{~m}$ b.g.I. which have been normalised to the concentrations of the conservative tracer $\mathrm{Br}$. All components were added simultaneously at day 20 (orange line), and the two redox events are marked with dashed vertical blue lines. It should be noted, and as discussed in the manuscript, the overall mechanisms for $\mathrm{Br}$ movement/loss from this depth were different from the contaminants $\mathrm{Sr}$, Cs and $\mathrm{Nd}$. However, the comparison between components upon shorter time scales (esp. redox events) does provide a degree of insight into their relative mobility. 


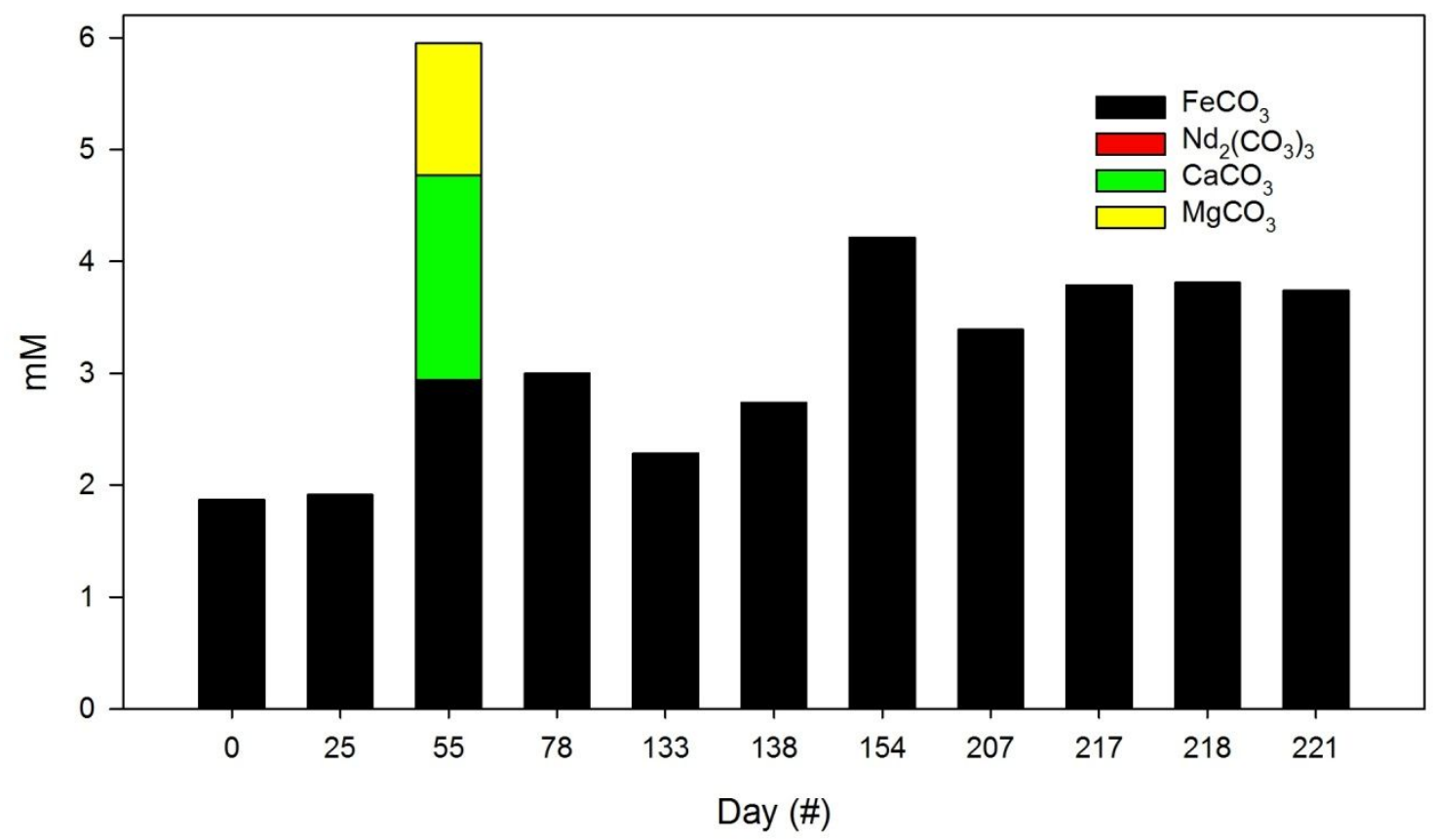

Figure S3.5: Quantity of carbonate minerals formed at thermodynamic equilibrium at $2.8 \mathrm{~m}$ b.g.l. water sampling point. Calculations were performed using Visual Minteq version $3.1^{13}$ based on the measured aqueous concentrations being at thermodynamic equilibrium and the relevant minerals being oversaturated. Although neodymium carbonate was predicted to precipitate (at Day 25), due to relatively minor concentrations of Nd present, quantities $<3 \mu \mathrm{M}$ cannot be seen. Calcite and dolomite were only present at day 55 . 


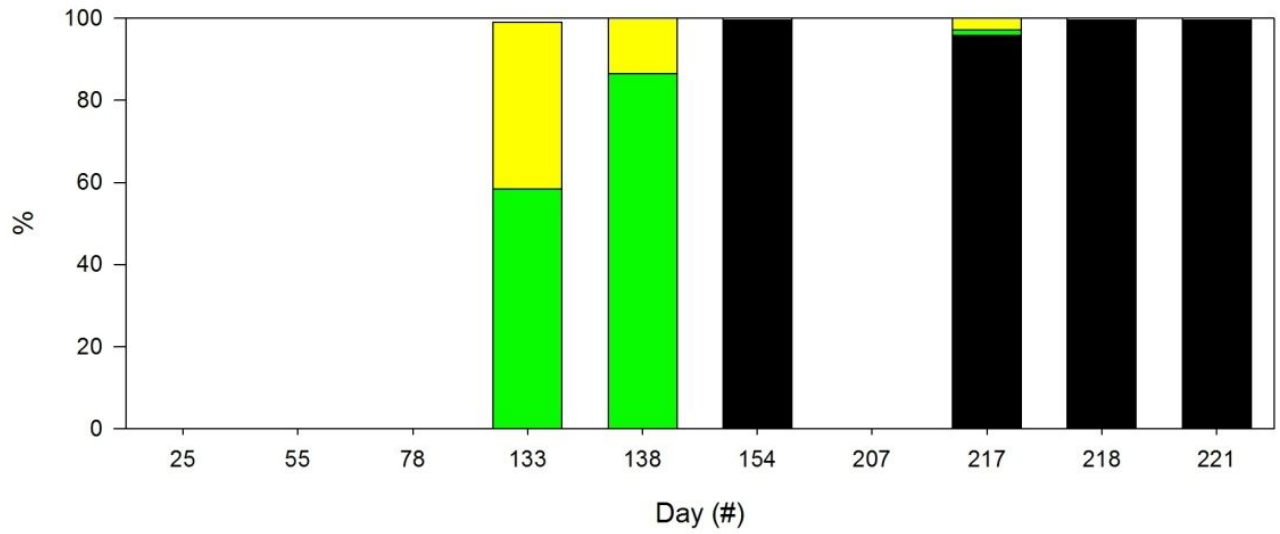

$1.3 \mathrm{~m}$ b.g.l.

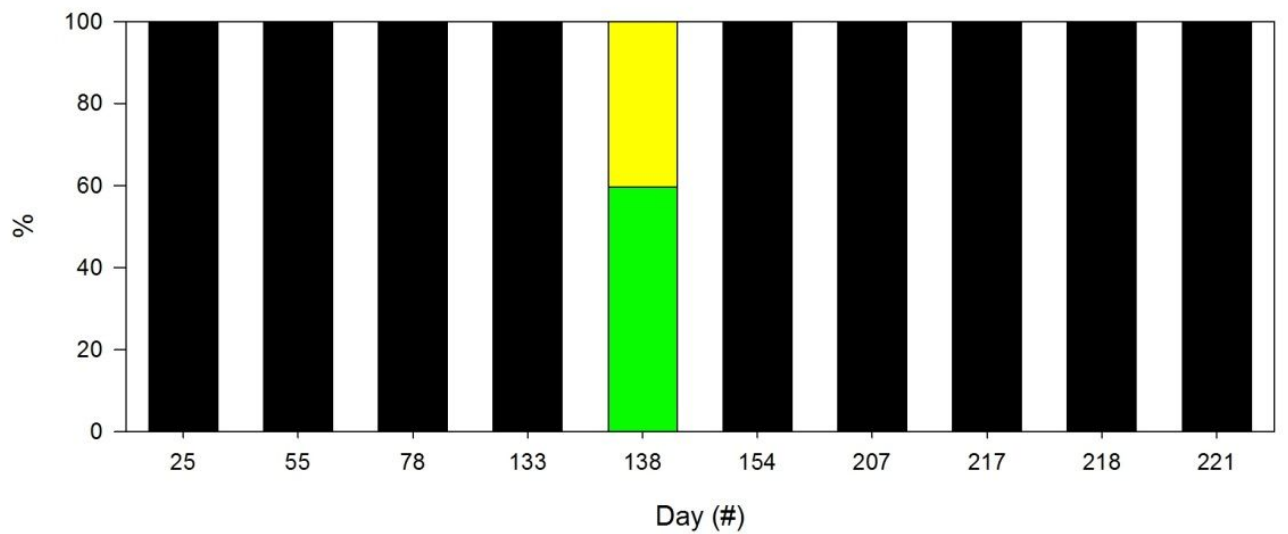

$1.8 \mathrm{~m}$ b.g.l.

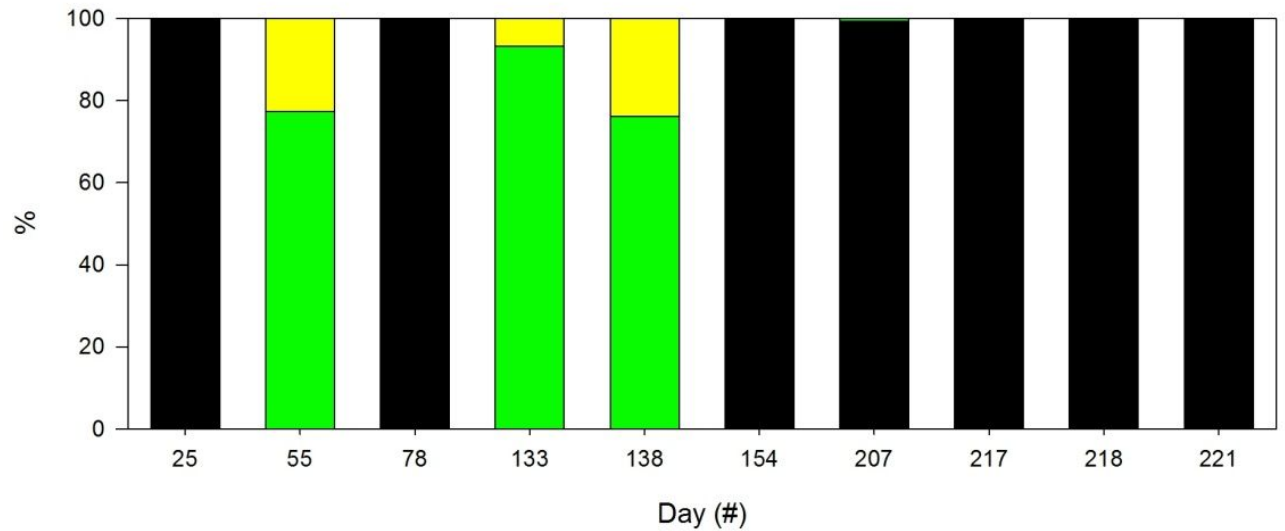

$2.3 \mathrm{~m}$ b.g.l.

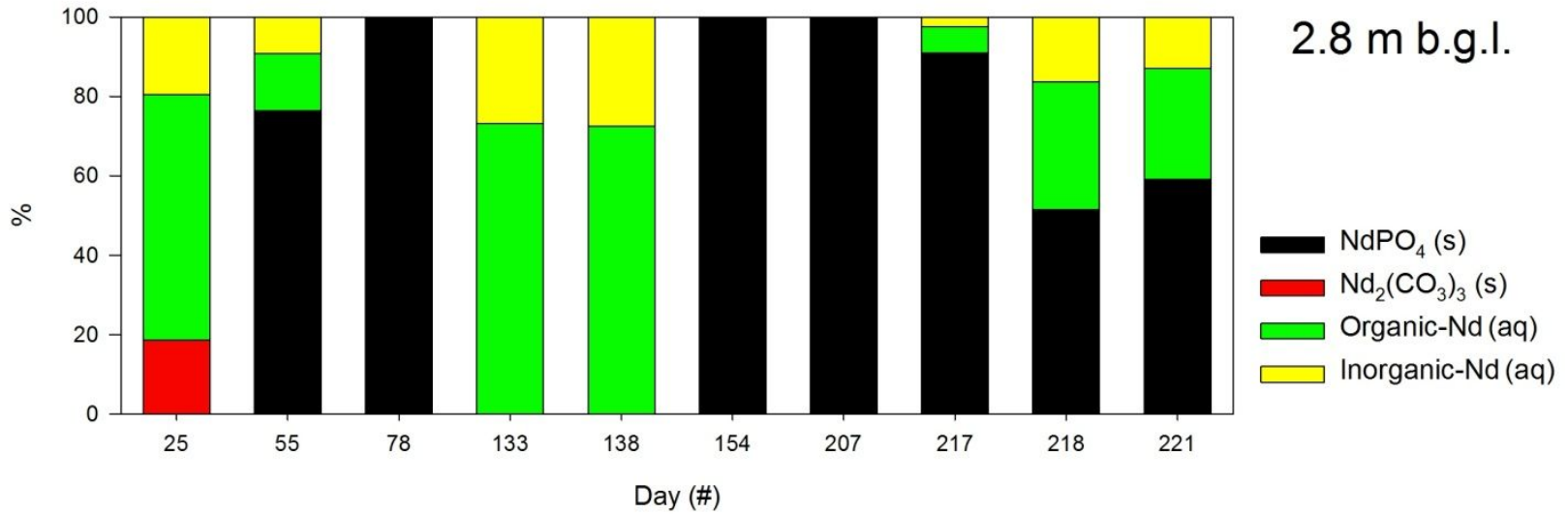

Figure S3.6: Solid (Nd-phosphate, Nd-carbonate) and aqueous (organic- and inorganic-bound) Nd-components present at thermodynamic equilibrium within individual depths and time points. Calculations were performed using Visual Minteq version 3.1.13 Organic aqueous components were the summation of fulvic- and humic-bound $\mathrm{Nd}$, and inorganic components the sum of dominant carbonate, sulfate and hydrolysed $\mathrm{Nd}$. 


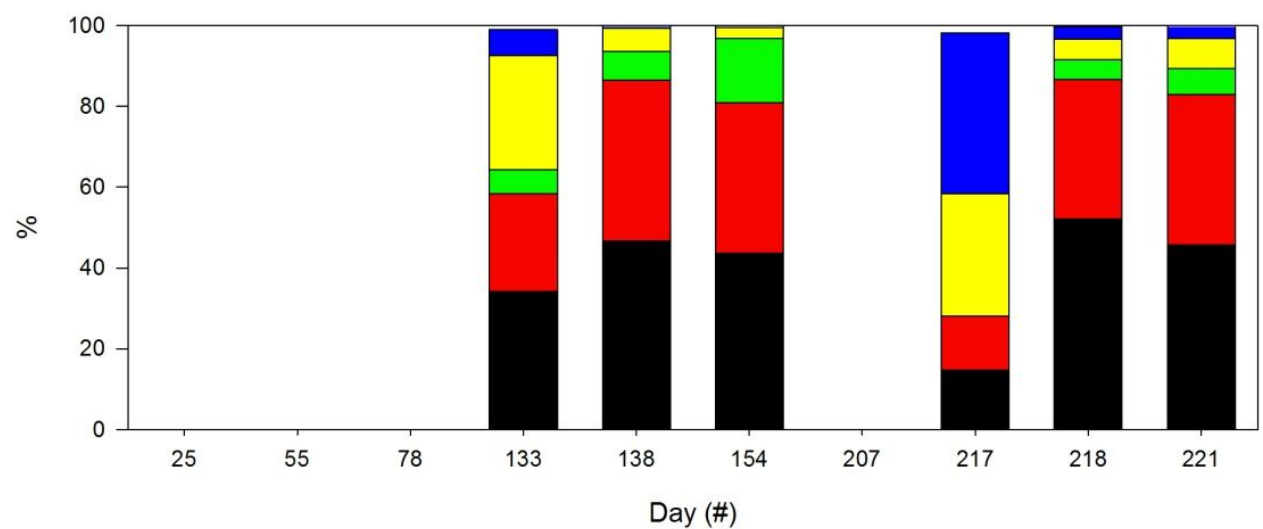

$1.3 \mathrm{~m}$ b.g.l.

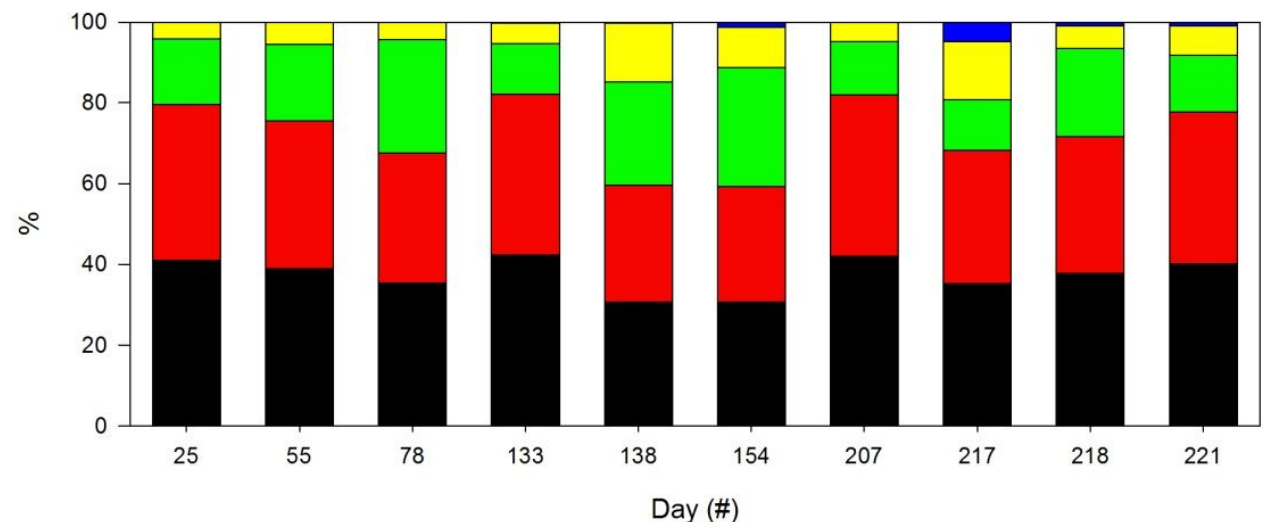

\section{$1.8 \mathrm{~m}$ b.g.l.}
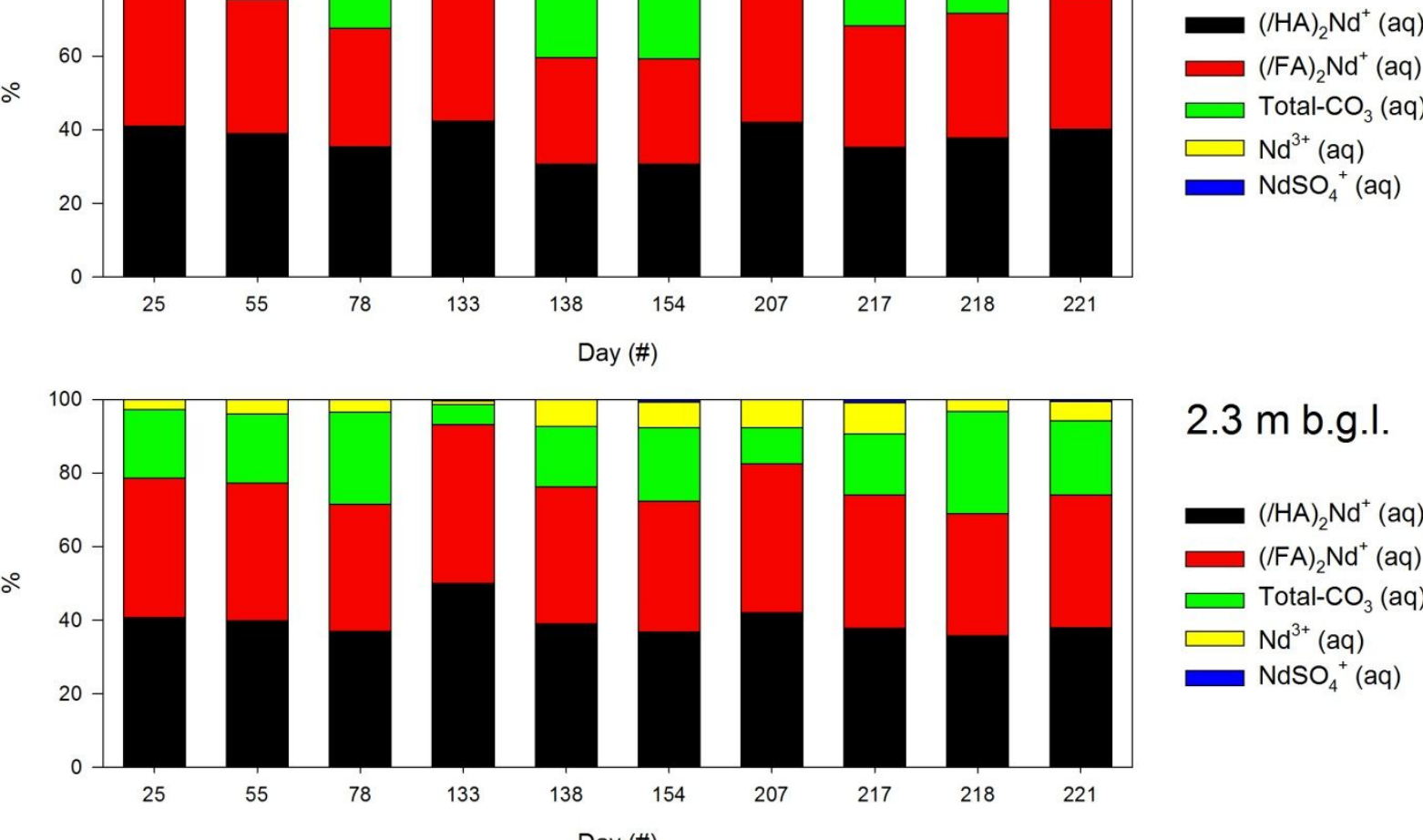

$2.3 \mathrm{~m}$ b.g.l.
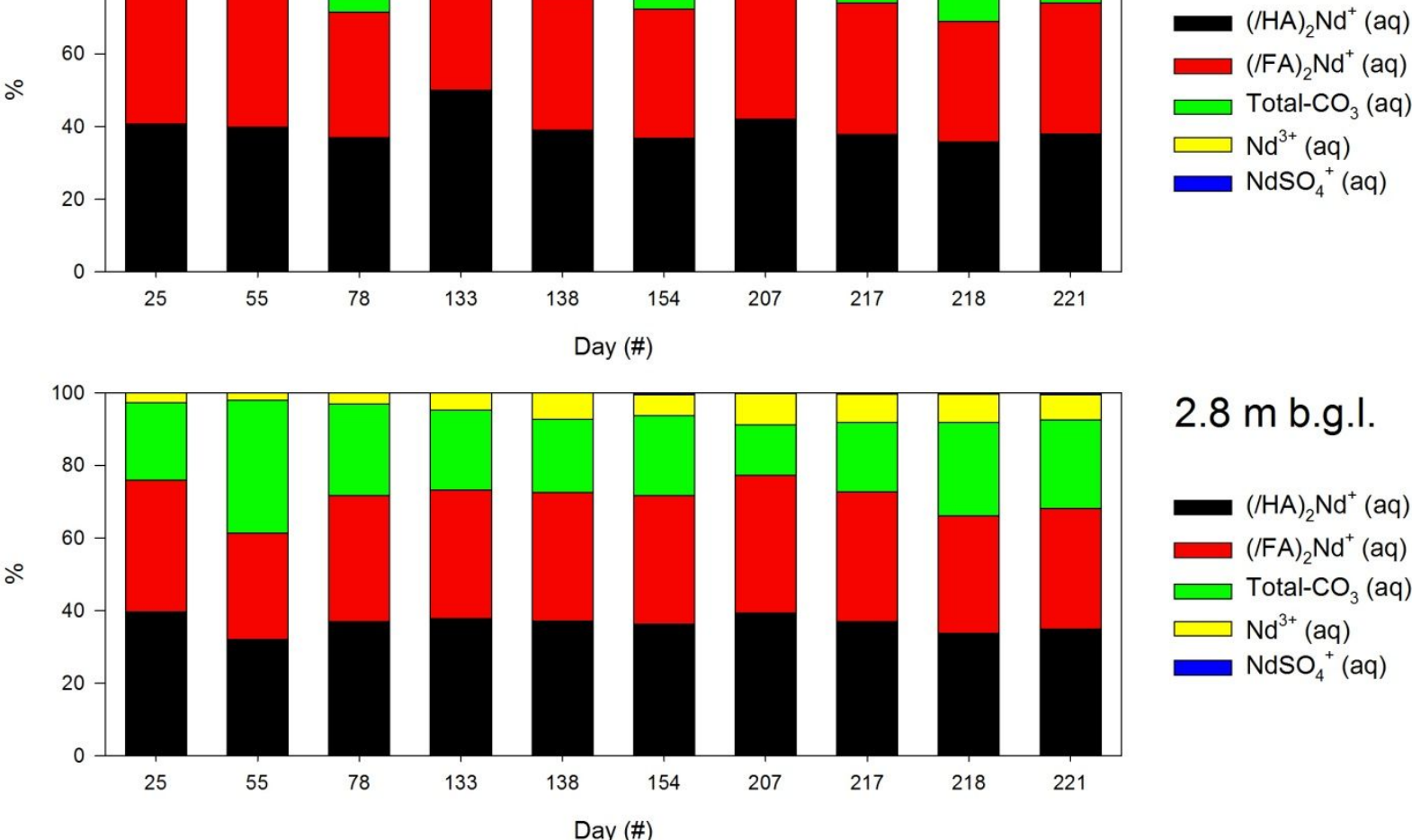

\section{$2.8 \mathrm{~m}$ b.g.l.}

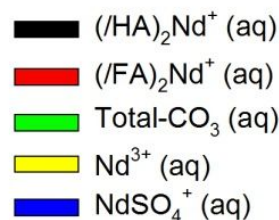

Figure S3.7: Aqueous Nd-components present at thermodynamic equilibrium within individual depths and time points. Calculations were performed using Visual Minteq version 3.1.13 The components /HA and /FA refer to humic and fulvic acid complexes, respectively. For brevity, total aqueous $\mathrm{Nd}$ carbonate complexes are shown collectively

(Total- $\left.\mathrm{CO}_{3}\right)$, composed primarily of $\mathrm{NdCO}_{3}{ }^{+}(\mathrm{aq})$ and $\mathrm{NdHCO}_{3}{ }^{2+}(\mathrm{aq})$ and, to a lesser extent, of $\mathrm{Nd}\left(\mathrm{CO}_{3}\right)^{2-}(\mathrm{aq})$. 


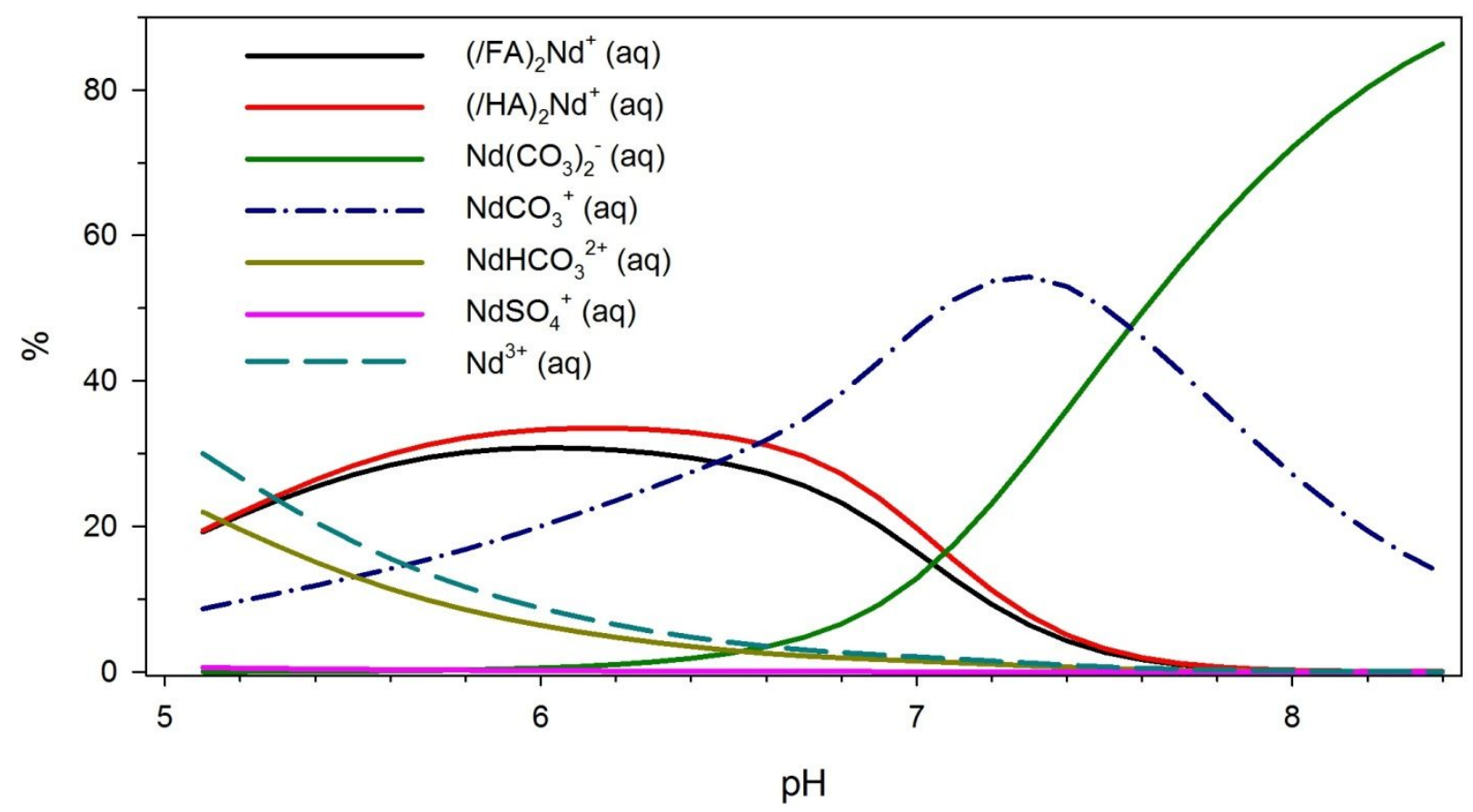

Figure S3.8: Aqueous Nd-components present at thermodynamic equilibrium across the environmentally relevant $\mathrm{pH}$ range 5 to 8.5. Calculations were performed using Visual Minteq version $3.1^{13}$ using an example sample $(1.8 \mathrm{~m}$ b.g.l. on day 138 where the measured $\mathrm{pH}$ was 5.65). The components /HA and /FA refer to humic and fulvic acid complexes, respectively.

Table S3.1: Chemical parameters of replica trench waters and stored rainwater.

\begin{tabular}{|c|c|c|c|c|c|c|c|c|c|c|c|}
\hline 1.3 m b.g.l. & Day & & & & & & & & & & \\
\hline Parameter & 0 & 25 & 55 & 78 & 133 & 138 & 154 & 207 & 217 & 218 & 221 \\
\hline $\mathrm{pH}$ & & & & & 6.26 & 6.19 & 6.49 & & 4.72 & 6.37 & 6.07 \\
\hline ORP (mV) & & & & & 299 & 153.4 & 152.8 & & 316.6 & 281 & 185.9 \\
\hline $\mathrm{Al}(\mathrm{ppm})$ & & & & & 0.03 & 0.07 & 0.04 & & 0.05 & 0.06 & 0.17 \\
\hline $\mathrm{Br}(\mathrm{ppm})$ & & & & & 3.60 & 6.39 & 10.44 & & 0.31 & 1.79 & 4.79 \\
\hline $\mathrm{Ca}(\mathrm{ppm})$ & & & & & 7 & 41 & 33.55 & & 7.44 & 9.15 & 14.53 \\
\hline $\mathrm{Cl}(\mathrm{ppm})$ & & & & & 27.10 & 47.02 & 77.36 & & 27.66 & 38.00 & 99.80 \\
\hline Cs (ppm) & & & & & 0.02 & 0.07 & 0.14 & & 0.05 & 0.11 & 0.16 \\
\hline DIC (ppm) & & & & & 4.54 & 46.22 & 100.06 & & 0.85 & 16.55 & 45.31 \\
\hline DOC (ppm) & & & & & 8.18 & 25.82 & 44.22 & & 10.26 & 14.55 & 29.23 \\
\hline $\mathrm{Fe}(\mathrm{ppm})$ & & & & & 9.68 & 29.30 & 54.15 & & 0.21 & 1.52 & 17.58 \\
\hline $\mathrm{K}(\mathrm{ppm})$ & & & & & 3.1 & 15.6 & 26.67 & & 4.77 & 9.51 & 15.03 \\
\hline Li (ppm) & & & & & 0.02 & 0.06 & 0.12 & & 0.02 & 0.05 & 0.10 \\
\hline $\mathrm{Mg}(\mathrm{ppm})$ & & & & & 1.75 & 15.8 & 29.54 & & 3.13 & 5.03 & 14.24 \\
\hline Mn (ppm) & & & & & 0.00 & 0.00 & 0.00 & & 0.00 & 0.00 & 0.00 \\
\hline $\mathrm{Na}(\mathrm{ppm})$ & & & & & 15.56 & 26.2 & 63.2 & & 19.62 & 28.34 & 39.38 \\
\hline $\mathrm{Nd}(\mathrm{ppm})$ & & & & & 0.003 & 0.005 & 0.004 & & 0.002 & 0.003 & 0.008 \\
\hline $\mathrm{P}(\mathrm{ppm})$ & & & & & 0 & 0 & 0.49 & & 0.03 & 0.06 & 0.42 \\
\hline Si (ppm) & & & & & 7.87 & 10 & 9.06 & & 7.49 & 9.28 & 16.58 \\
\hline S (ppm) & & & & & 2.99 & 2.4 & 4.91 & & 18.2 & 16.39 & 8.54 \\
\hline $\mathrm{S}^{2-}(\mathrm{ppm})$ & & & & & 0 & 0 & 0 & & 0 & 0 & 0 \\
\hline $\mathrm{Sr}(\mathrm{ppm})$ & & & & & 0.05 & 0.36 & 0.87 & & 0.14 & 0.27 & 0.67 \\
\hline Charge Diff (\%) & & & & & 5.73 & 2.69 & 5.24 & & 13.11 & 6.51 & 7.59 \\
\hline
\end{tabular}




\begin{tabular}{|c|c|c|c|c|c|c|c|c|c|c|c|}
\hline $\begin{array}{c}1.8 \text { m b.g.l. } \\
\text { Parameter }\end{array}$ & $\begin{array}{c}\text { Day } \\
0\end{array}$ & 25 & 55 & 78 & 133 & 138 & 154 & 207 & 217 & 218 & 221 \\
\hline $\mathrm{pH}$ & 6.07 & 6.1 & 6.08 & 6.41 & 5.84 & 5.65 & 5.95 & 6.01 & 5.45 & 6.26 & 5.9 \\
\hline ORP $(m V)$ & 169 & 144.6 & 157.5 & 140.3 & 141 & 139.3 & 150.2 & 130.9 & 167.9 & 161.7 & 150 \\
\hline $\mathrm{Al}(\mathrm{ppm})$ & 0.4 & 0 & 0 & 0.1 & 0 & 0.03 & 0.03 & 0.02 & 0.05 & 0.05 & 0.05 \\
\hline $\mathrm{Br}(\mathrm{ppm})$ & 0.00 & 34.45 & 33.20 & 30.1 & 20.58 & 20.11 & 15.79 & 18.32 & 7.18 & 10.63 & 21.29 \\
\hline $\mathrm{Ca}(\mathrm{ppm})$ & 91.2 & 94.5 & 106.4 & 108 & 74.01 & 88.97 & 31.06 & 32.03 & 16.95 & 24.06 & 24.04 \\
\hline $\mathrm{Cl}$ (ppm) & 124.50 & 155.88 & 128.40 & 141.80 & 125.40 & 120.38 & 115.01 & 111.48 & 91.63 & 239.83 & 188.46 \\
\hline Cs (ppm) & 0.00 & 0.06 & 0.09 & 0.05 & 0.02 & 0.02 & 0.02 & 0.02 & 0.04 & 0.04 & 0.04 \\
\hline DIC (ppm) & 128.82 & 127.60 & 112.30 & 111.91 & 106.90 & 107.04 & 113.14 & 97.04 & 54.87 & 78.01 & 74.75 \\
\hline $\mathrm{DOC}(\mathrm{ppm})$ & 60.68 & 77.02 & 58.62 & 57.73 & 58.70 & 52.78 & 52.34 & 75.68 & 37.48 & 48.39 & 53.16 \\
\hline $\mathrm{Fe}(\mathrm{ppm})$ & 130.42 & 147.58 & 133.05 & 149.43 & 154.75 & 138.87 & 151.47 & 157.22 & 90.15 & 120.32 & 118.93 \\
\hline $\mathrm{K}(\mathrm{ppm})$ & 35.3 & 38.7 & 38.5 & 36.5 & 28.1 & 30.14 & 34.09 & 35.5 & 23.39 & 28.16 & 28.07 \\
\hline Li (ppm) & 0.00 & 0.53 & 0.32 & 0.23 & 0.13 & 0.13 & 0.12 & 0.12 & 0.14 & 0.18 & 0.18 \\
\hline $\mathrm{Mg}(\mathrm{ppm})$ & 38.9 & 40.2 & 37.1 & 39.6 & 28.09 & 32.6 & 37.7 & 40.49 & 21.09 & 29.58 & 28.64 \\
\hline $\mathrm{Mn}(\mathrm{ppm})$ & 0.00 & 0.00 & 0.00 & 0.00 & 0.00 & 0.00 & 0.00 & 0.00 & 0.00 & 0.00 & 0.00 \\
\hline $\mathrm{Na}(\mathrm{ppm})$ & 68.3 & 76.7 & 66.2 & 69.9 & 57.2 & 59.9 & 93.48 & 105.1 & 63.97 & 77.8 & 75.54 \\
\hline $\mathrm{Nd}(\mathrm{ppm})$ & 0.004 & 0.014 & 0.014 & 0.010 & 0.006 & 0.006 & 0.006 & 0.006 & 0.009 & 0.010 & 0.010 \\
\hline $\mathrm{P}(\mathrm{ppm})$ & 0.40 & 0.20 & 0.30 & 0.30 & 0.30 & 0.00 & 0.15 & 0.14 & 0.23 & 0.28 & 0.31 \\
\hline Si (ppm) & 9.9 & 8.9 & 7.1 & 8.5 & 10.4 & 11.4 & 7.3 & 7.63 & 13.04 & 13.41 & 15.25 \\
\hline S (ppm) & 1.4 & 1.3 & 1.3 & 1.1 & 1.9 & 1 & 6.31 & 0.58 & 10.82 & 6.23 & 5.47 \\
\hline $\mathrm{S}^{2-}(\mathrm{ppm})$ & 0 & 0 & 0 & 0 & 0 & 0 & 0 & 0 & 0 & 0 & 0 \\
\hline Sr (ppm) & 0.44 & 1.08 & 1.27 & 0.95 & 0.70 & 0.71 & 0.71 & 0.68 & 0.82 & 1.03 & 1.04 \\
\hline Charge Diff (\%) & 4.92 & 0.44 & 5.59 & 7.08 & 6.02 & 3.24 & 2.87 & 11.28 & 9.01 & 10.99 & 6.36 \\
\hline
\end{tabular}

\begin{tabular}{|c|c|c|c|c|c|c|c|c|c|c|c|}
\hline $\begin{array}{c}2.3 \text { m b.g.l. } \\
\text { Parameter }\end{array}$ & $\begin{array}{c}\text { Day } \\
0 \\
\end{array}$ & 25 & 55 & 78 & 133 & 138 & 154 & 207 & 217 & 218 & 221 \\
\hline $\mathrm{pH}$ & 5.83 & 6.31 & 6.17 & 6.37 & 6.02 & 5.73 & 5.83 & 5.39 & 5.62 & 6.42 & 6.03 \\
\hline ORP $(\mathrm{mV})$ & 181 & 136 & 143.9 & 142.1 & 140 & 134 & 142.4 & 134.5 & 138.8 & 136.6 & 134.9 \\
\hline $\mathrm{Al}$ (ppm) & 0.6 & 0 & 0 & 0 & 0 & 0.01 & 0.01 & 0.01 & 0.02 & 0.02 & 0.03 \\
\hline $\mathrm{Br}(\mathrm{ppm})$ & 0.00 & 28.29 & 42.30 & 34.40 & 25.49 & 25.08 & 20.23 & 15.66 & 23.22 & 18.71 & 43.00 \\
\hline $\mathrm{Ca}(\mathrm{ppm})$ & 108.7 & 140 & 133.3 & 140.4 & 107.8 & 138.99 & 48.4 & 44.92 & 43.56 & 43.36 & 41.82 \\
\hline $\mathrm{Cl}$ (ppm) & 145.70 & 166.25 & 150.10 & 151.90 & 137.36 & 134.52 & 131.59 & 117.22 & 123.14 & 100.82 & 236.56 \\
\hline Cs (ppm) & 0.00 & 0.25 & 0.28 & 0.05 & 0.03 & 0.03 & 0.02 & 0.02 & 0.06 & 0.06 & 0.05 \\
\hline DIC (ppm) & 151.18 & 155.73 & 145.14 & 142.74 & 161.48 & 140.56 & 149.77 & 114.02 & 131.44 & 138.06 & 140.25 \\
\hline DOC (ppm) & 84.59 & 93.84 & 81.94 & 74.06 & 74.42 & 70.85 & 75.06 & 100.36 & 72.09 & 70.32 & 69.91 \\
\hline $\mathrm{Fe}(\mathrm{ppm})$ & 153.12 & 158.66 & 162.26 & 173.98 & 173.05 & 164.21 & 185.10 & 177.86 & 174.39 & 175.38 & 169.70 \\
\hline $\mathrm{K}(\mathrm{ppm})$ & 48.6 & 53.1 & 53.5 & 47.8 & 42.85 & 42.44 & 51.23 & 49.76 & 46.48 & 46.65 & 45.38 \\
\hline Li (ppm) & 0.00 & 0.68 & 0.58 & 0.29 & 0.19 & 0.20 & 0.17 & 0.15 & 0.31 & 0.31 & 0.32 \\
\hline Mg (ppm) & 36.1 & 42.2 & 44.3 & 44.9 & 35.67 & 41.41 & 50.22 & 47.44 & 44.64 & 45.35 & 44.31 \\
\hline Mn (ppm) & 0.00 & 0.00 & 0.00 & 0.00 & 0.00 & 0.00 & 0.00 & 0.00 & 0.00 & 0.00 & 0.00 \\
\hline $\mathrm{Na}(\mathrm{ppm})$ & 71.3 & 84.3 & 86.9 & 74.4 & 63.4 & 72.57 & 112.3 & 108.03 & 103.11 & 105.1 & 102.85 \\
\hline $\mathrm{Nd}(\mathrm{ppm})$ & 0.00 & 0.008 & 0.014 & 0.002 & 0.002 & 0.001 & 0.001 & 0.001 & 0.003 & 0.003 & 0.003 \\
\hline $\mathrm{P}(\mathrm{ppm})$ & 0.3 & 0.4 & 0.5 & 0.5 & 0.3 & 0 & 0.36 & 0.33 & 0.47 & 0.56 & 0.73 \\
\hline Si (ppm) & 10.6 & 11.1 & 13.9 & 10.2 & 11.5 & 12.61 & 9.16 & 8.86 & 20.25 & 18.5 & 19.25 \\
\hline $\mathrm{S}(\mathrm{ppm})$ & 1.5 & 1.6 & 2.1 & 1.3 & 0.9 & 1.39 & 6.56 & 0.98 & 2.88 & 2.06 & 5.24 \\
\hline $\mathrm{S}^{2-}(\mathrm{ppm})$ & 0 & 0 & 0 & 0 & 0 & 0 & 0 & 0 & 0 & 0 & 0 \\
\hline $\mathrm{Sr}(\mathrm{ppm})$ & 0.57 & 1.09 & 1.30 & 0.87 & 0.83 & 0.86 & 0.84 & 0.80 & 1.76 & 1.64 & 1.64 \\
\hline Charge Diff (\%) & 6.04 & 0.34 & 4.49 & 5.83 & 3.49 & 6.1 & 3.25 & 11.15 & 3.74 & 5.26 & 9.1 \\
\hline
\end{tabular}




\begin{tabular}{|c|c|c|c|c|c|c|c|c|c|c|c|}
\hline $\begin{array}{c}2.8 \text { m b.g.l. } \\
\text { Parameter }\end{array}$ & $\begin{array}{c}\text { Day } \\
0 \\
\end{array}$ & 25 & 55 & 78 & 133 & 138 & 154 & 207 & 217 & 218 & 221 \\
\hline $\mathrm{pH}$ & 5.75 & 6.33 & 6.68 & 6.37 & 6.02 & 5.76 & 5.89 & 5.17 & 5.66 & 5.83 & 5.9 \\
\hline ORP (mV) & 181 & 130.1 & 125 & 141 & 142.2 & 134.4 & 140 & 134.1 & 129.1 & 138.9 & 133.1 \\
\hline $\mathrm{Al}(\mathrm{ppm})$ & 0.5 & 0 & 0 & 0 & 0.02 & 0.02 & 0.01 & 0.01 & 0.03 & 0.04 & 0.04 \\
\hline $\mathrm{Br}(\mathrm{ppm})$ & 0.00 & 178.33 & 147.60 & 110.60 & 83.48 & 83.93 & 67.35 & 46.21 & 50.65 & 26.02 & 105.80 \\
\hline $\mathrm{Ca}(\mathrm{ppm})$ & 161.2 & 146.4 & 205 & 198.6 & 168.7 & 199.88 & 72.5 & 65.38 & 60.34 & 61.86 & 58.68 \\
\hline $\mathrm{Cl}$ (ppm) & 193.90 & 221.78 & 222.50 & 228.80 & 164.70 & 191.29 & 160.54 & 164.44 & 181.00 & 126.30 & 285.48 \\
\hline Cs (ppm) & 0.00 & 12.29 & 5.59 & 3.92 & 1.85 & 1.79 & 1.68 & 1.24 & 2.16 & 2.47 & 2.36 \\
\hline DIC (ppm) & 183.86 & 186.18 & 202.56 & 192.65 & 200.80 & 195.00 & 203.14 & 189.04 & 181.86 & 180.08 & 189.85 \\
\hline DOC (ppm) & 112.10 & 117.98 & 106.17 & 112.26 & 110.03 & 100.17 & 107.78 & 115.22 & 98.22 & 104.33 & 106.40 \\
\hline $\mathrm{Fe}(\mathrm{ppm})$ & 147.98 & 157.08 & 171.50 & 202.22 & 197.47 & 197.47 & 231.05 & 222.36 & 224.36 & 218.93 & 214.62 \\
\hline $\mathrm{K}(\mathrm{ppm})$ & 68.3 & 59.2 & 83.2 & 73 & 62.3 & 56.79 & 73.18 & 66.75 & 61.82 & 63.43 & 61.12 \\
\hline Li (ppm) & 0.00 & 12.88 & 6.70 & 4.30 & 2.60 & 2.64 & 2.42 & 1.79 & 2.79 & 3.16 & 3.09 \\
\hline $\mathrm{Mg}(\mathrm{ppm})$ & 45.51 & 46.9 & 61.7 & 62.1 & 49.8 & 53.5 & 66.44 & 61.69 & 58.93 & 59.6 & 58.16 \\
\hline Mn (ppm) & 0.00 & 0.00 & 0.00 & 0.00 & 0.00 & 0.00 & 0.00 & 0.00 & 0.00 & 0.00 & 0.00 \\
\hline $\mathrm{Na}(\mathrm{ppm})$ & 95.74 & 93.5 & 122.4 & 115 & 100.7 & 104.6 & 86.1 & 83.21 & 77.43 & 81.6 & 79.07 \\
\hline $\mathrm{Nd}(\mathrm{ppm})$ & 0.00 & 0.66 & 0.61 & 0.39 & 0.32 & 0.13 & 0.29 & 0.28 & 0.46 & 1.08 & 1.02 \\
\hline $\mathrm{P}(\mathrm{ppm})$ & 0.21 & 0 & 0.1 & 0.1 & 0 & 0 & 0.07 & 0.07 & 0.09 & 0.12 & 0.13 \\
\hline Si (ppm) & 10.25 & 9.5 & 10.8 & 10.3 & 10.91 & 12.2 & 9.06 & 8.51 & 18.92 & 17.24 & 17.71 \\
\hline S (ppm) & 1.72 & 1.7 & 2.4 & 1.7 & 1.32 & 1.5 & 6.93 & 1.61 & 3.88 & 3.21 & 5.83 \\
\hline $\mathrm{S}^{2-}(\mathrm{ppm})$ & 0 & 0 & 0 & 0 & 0 & 0 & 0 & 0 & 0 & 0 & 0 \\
\hline $\mathrm{Sr}(\mathrm{ppm})$ & 0.76 & 18.75 & 10.88 & 8.08 & 5.33 & 5.55 & 5.71 & 4.97 & 9.14 & 9.80 & 9.67 \\
\hline Charge Diff (\%) & 8.48 & 7.39 & 4.91 & 4.92 & 2.16 & 3.89 & 2.33 & 3.36 & 4.09 & 1.37 & 10.39 \\
\hline
\end{tabular}

\begin{tabular}{|c|c|}
\hline $\begin{array}{c}\text { Rainwater } \\
\text { Parameter }\end{array}$ & \\
\hline $\mathrm{pH}$ & 6.3 \\
$\mathrm{ORP}(\mathrm{mV})$ & 295 \\
$\mathrm{TDS}(\mathrm{g} / \mathrm{L})$ & $<0.01$ \\
$\mathrm{Al}(\mathrm{ppm})$ & 0 \\
$\mathrm{Br}(\mathrm{ppm})$ & 0 \\
\hline $\mathrm{Ca}(\mathrm{ppm})$ & 0.64 \\
$\mathrm{Cl}(\mathrm{ppm})$ & 9.10 \\
\hline $\mathrm{Cs}(\mathrm{ppm})$ & 0 \\
\hline $\mathrm{DIC}(\mathrm{ppm})$ & 0 \\
\hline $\mathrm{DOC}(\mathrm{ppm})$ & 0 \\
\hline $\mathrm{Fe}(\mathrm{ppm})$ & 0 \\
\hline $\mathrm{K}(\mathrm{ppm})$ & 0.18 \\
\hline $\mathrm{Li}(\mathrm{ppm})$ & 0 \\
$\mathrm{Mg}(\mathrm{ppm})$ & 0.37 \\
\hline $\mathrm{Mn}(\mathrm{ppm})$ & 0 \\
\hline $\mathrm{Na}(\mathrm{ppm})$ & 8.31 \\
\hline $\mathrm{Nd}(\mathrm{ppm})$ & 0 \\
$\mathrm{P}(\mathrm{ppm})$ & 0 \\
\hline $\mathrm{Si}(\mathrm{ppm})$ & 0 \\
$\mathrm{~S}(\mathrm{ppm})$ & 0 \\
$\mathrm{~S}{ }^{2-}(\mathrm{ppm})$ & 0 \\
$\mathrm{Sr}(\mathrm{ppm})$ & 0 \\
\hline
\end{tabular}




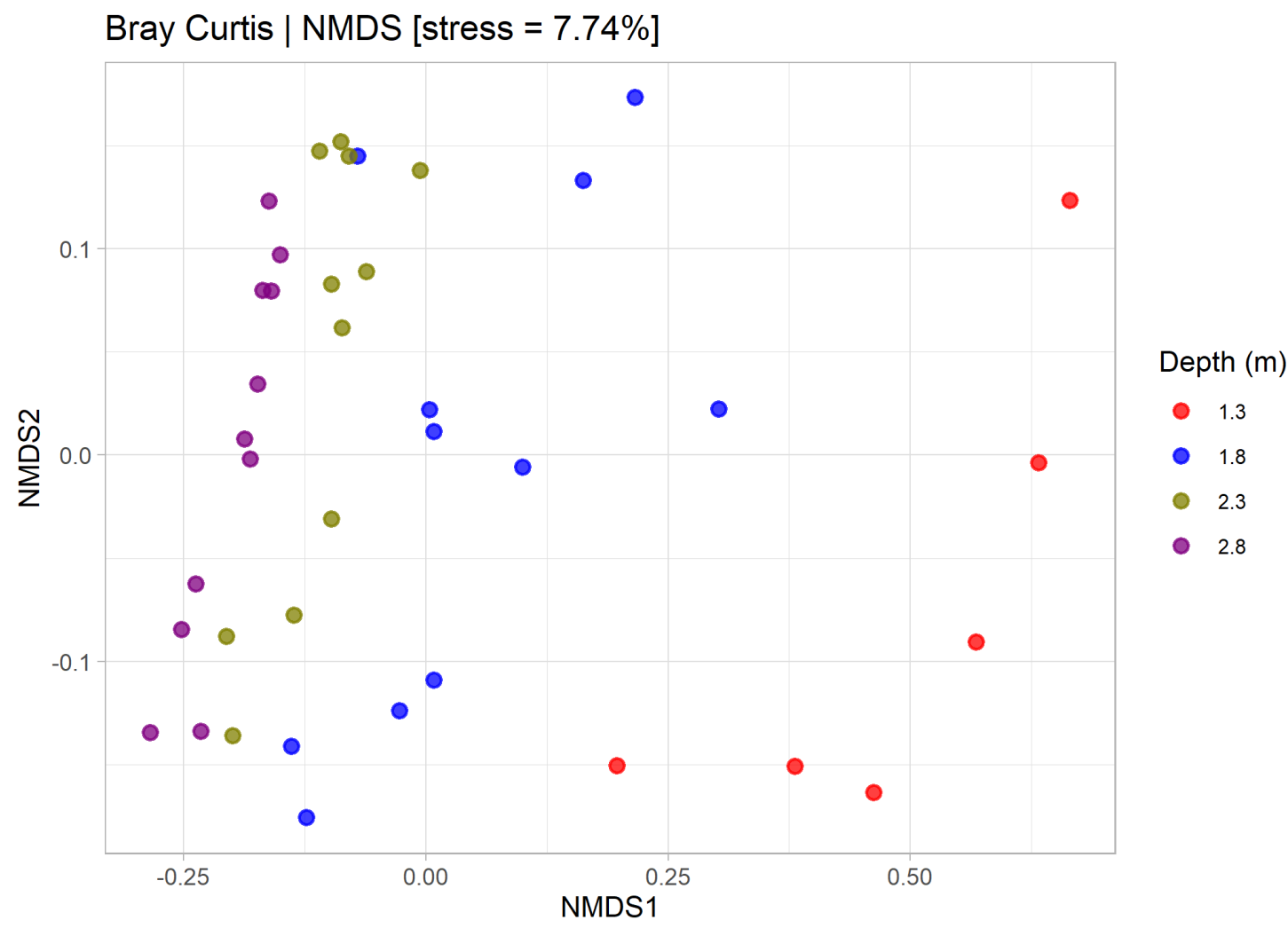

Figure S4.1: Non-metric multi-dimensional scaling (NMDS) plot of microbial community composition using the Bray Curtis dissimilarity index. Sample colour reflects individual sampling depths.

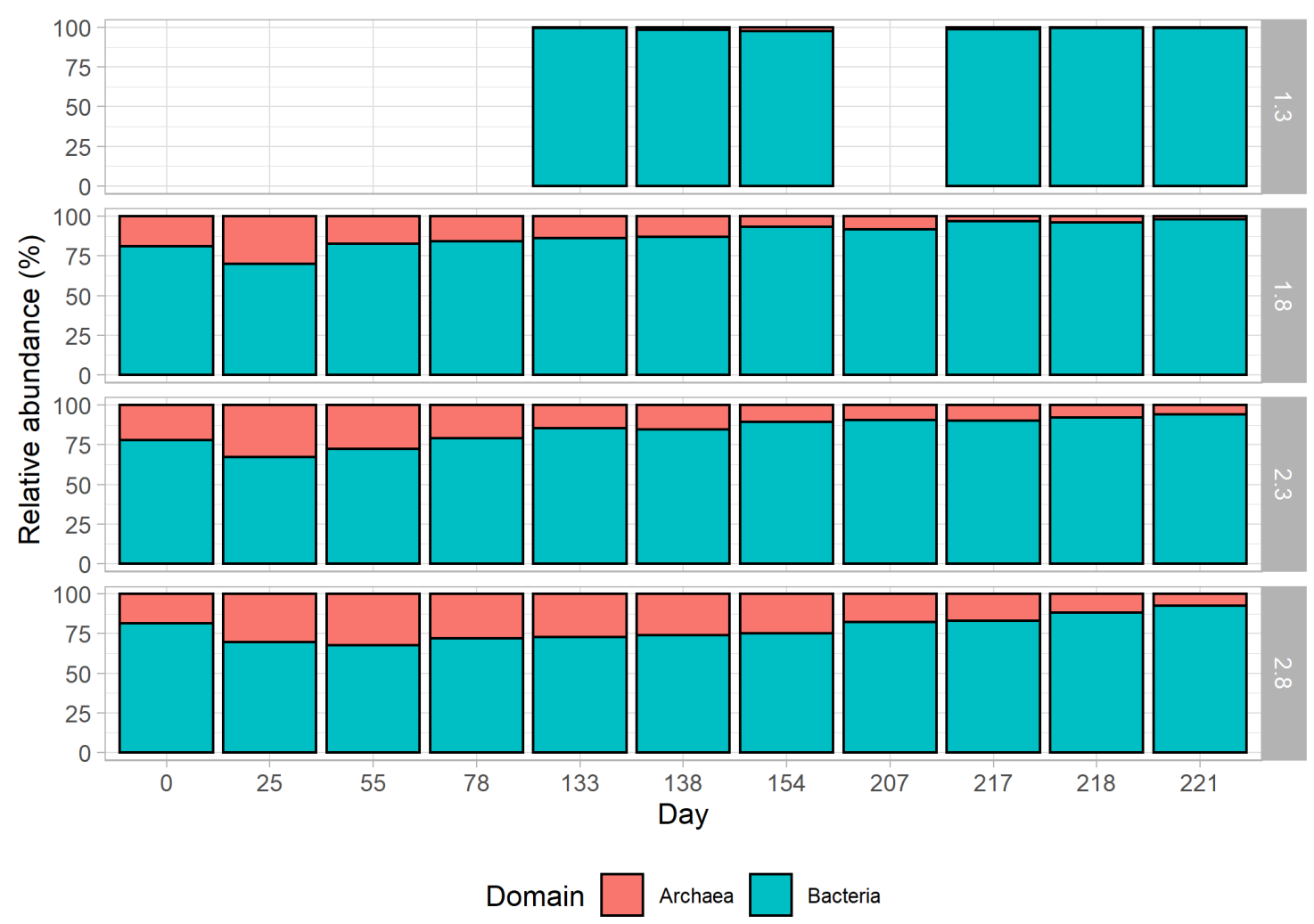

Figure S4.2: Domain level abundance from $16 S$ sequencing data. 


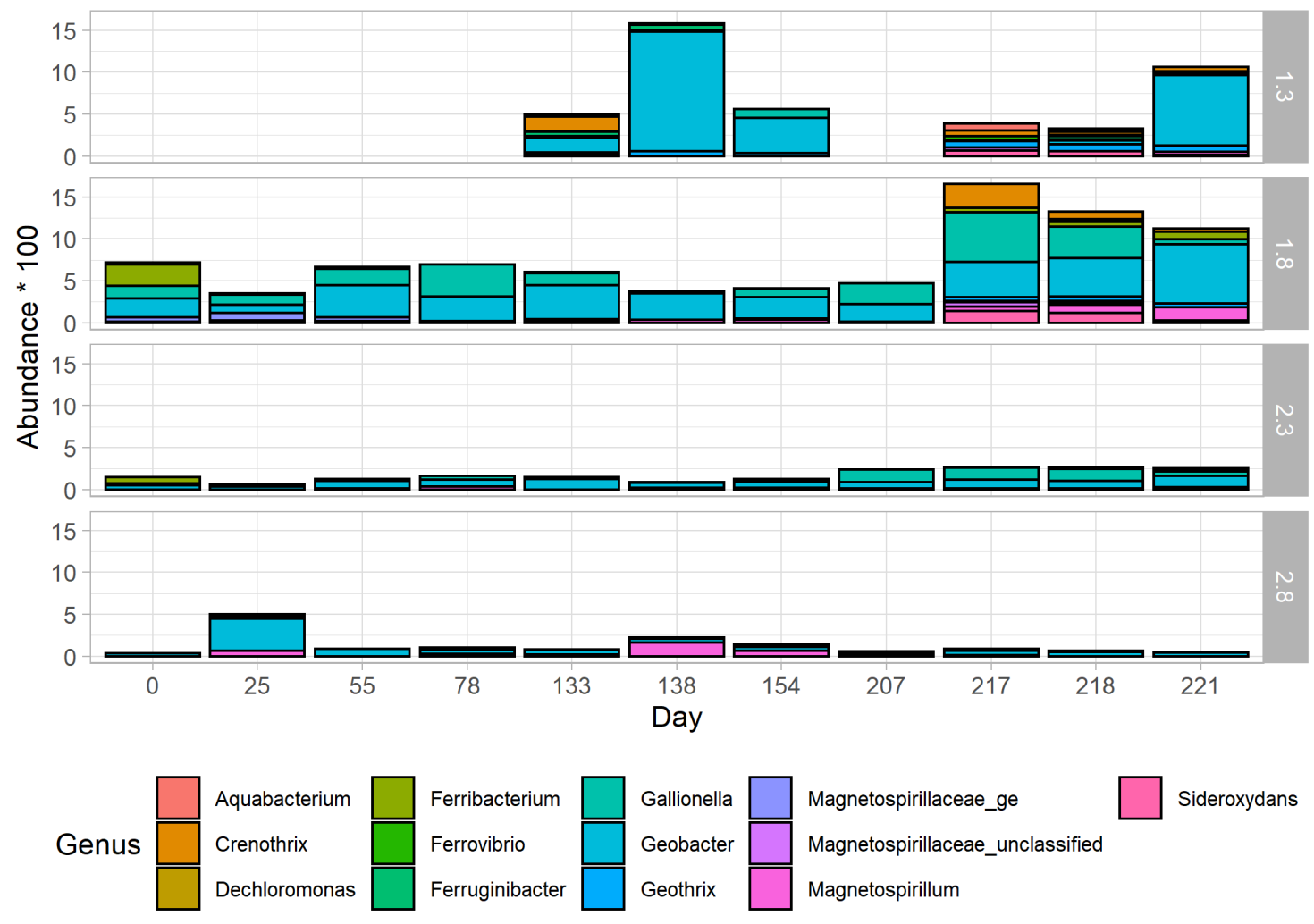

Figure S4.3: Relative abundance of genera associated with iron cycling. Crenothrix is included as it is usually associated with iron-cycling bacteria despite not being directly involved in the iron cycle.

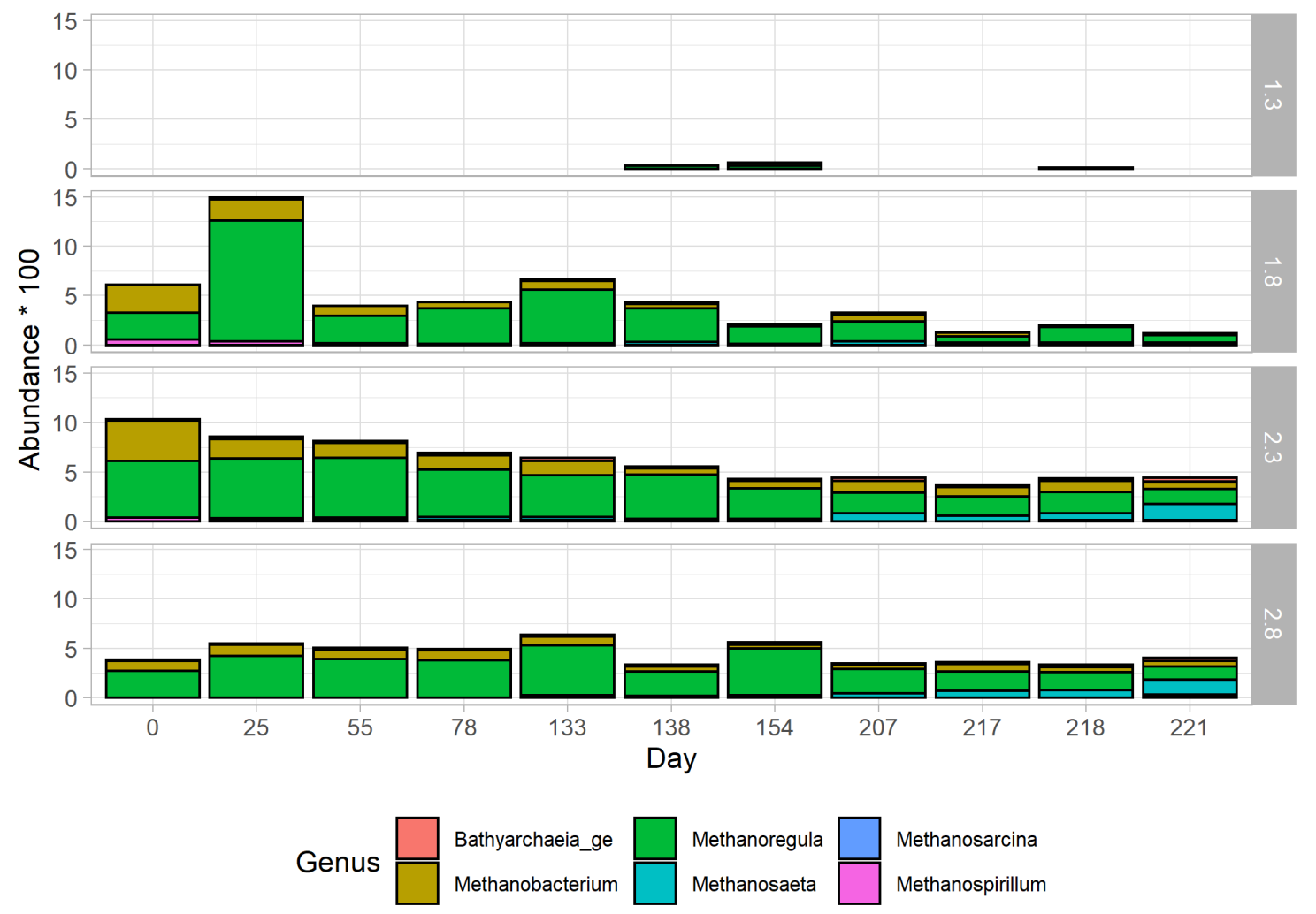

Figure S4.4: Relative abundance of methanogens at genus level. 


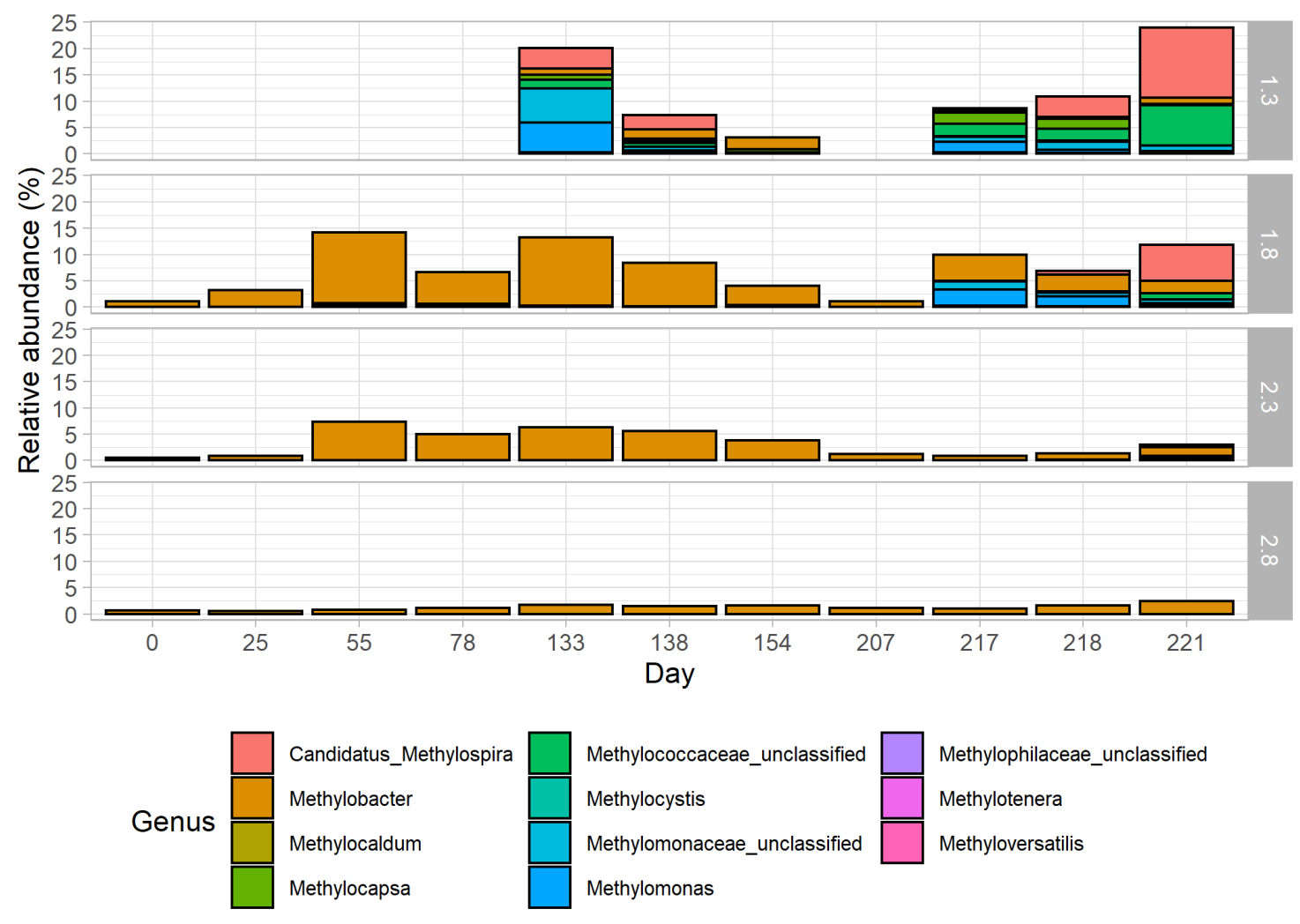

Figure S4.5: Relative abundance of methanotrophs at genus level.

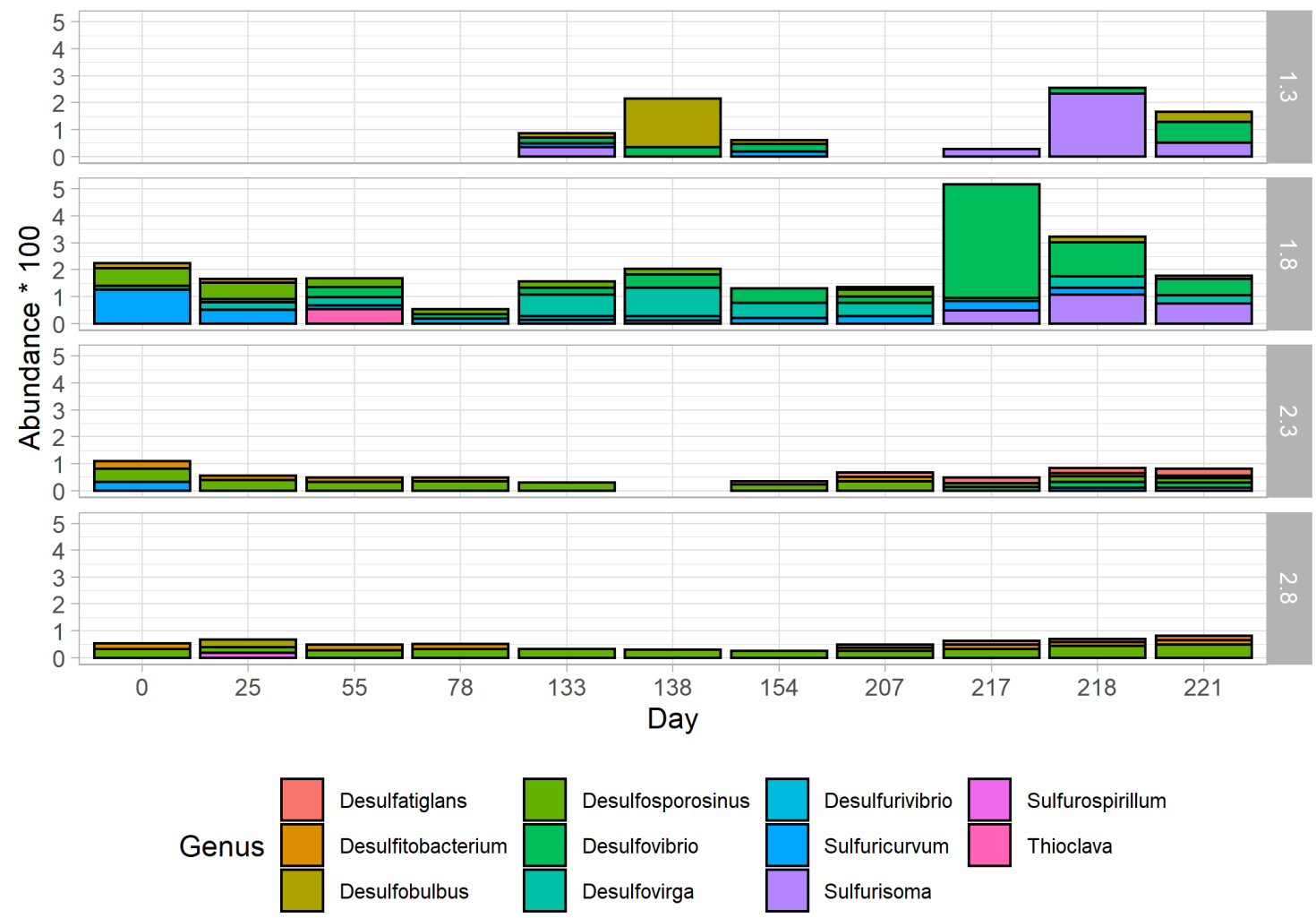

Figure S4.6: Relative abundance of genera involved in the dissimilatory sulfur cycle. 


\section{References}

(1) Cendón, D. I.; Hughes, C. E.; Harrison, J. J.; Hankin, S. I.; Johansen, M. P.; Payne, T. E.; Wong, H.; Rowling, B.; Vine, M.; Wilsher, K.; Guinea, A.; Thiruvoth, S., Identification of sources and processes in a low-level radioactive waste site adjacent to landfills: groundwater hydrogeochemistry and isotopes. Australian Journal of Earth Sciences 2015, 62, (1), 123-141.

(2) Payne, T. E.; Harrison, J. J.; Hughes, C. E.; Johansen, M. P.; Thiruvoth, S.; Wilsher, K. L.; Cendón, D. I.; Hankin, S. I.; Rowling, B.; Zawadzki, A., Trench 'bathtubbing' and surface plutonium contamination at a legacy radioactive waste site. Environmental Science \& Technology 2013, 47, (23), 13284-13293.

(3) Payne, T. E. Background report on the Little Forest Burial Ground legacy waste site (ANSTO E780); Institute for Environmental Research, Australian Nuclear Science and Technology Organisation: $2012 ; \mathrm{p} 25$.

(4) Zhou, X.; Mopper, K., Determination of photochemically produced hydroxyl radicals in seawater and freshwater. Marine Chemistry 1990, 30, (C), 71-88.

(5) Vázquez-Campos, X.; Kinsela, A. S.; Bligh, M. W.; Harrison, J. J.; Payne, T. E.; Waite, T. D., Response of microbial community function to fluctuating geochemical conditions within a legacy radioactive waste trench environment. Applied and Environmental Microbiology 2017, 83, (17 ), e0072917.

(6) Parada, A. E.; Needham, D. M.; Fuhrman, J. A., Every base matters: Assessing small subunit rRNA primers for marine microbiomes with mock communities, time series and global field samples. Environmental Microbiology 2016, 18, (5), 1403-1414.

(7) Apprill, A.; McNally, S.; Parsons, R.; Weber, L., Minor revision to V4 region SSU rRNA 806R gene primer greatly increases detection of SAR11 bacterioplankton. Aquatic Microbial Ecology 2015, 75, (2), 129-137.

(8) Schloss, P. D.; Westcott, S. L.; Ryabin, T.; Hall, J. R.; Hartmann, M.; Hollister, E. B.; Lesniewski, R. A.; Oakley, B. B.; Parks, D. H.; Robinson, C. J.; Sahl, J. W.; Stres, B.; Thallinger, G. G.; Van Horn, D. J.; Weber, C. F., Introducing mothur: Open-source, platform-independent, community-supported software for describing and comparing microbial communities. Applied and Environmental Microbiology 2009, 75, (23), 7537-7541.

(9) Rognes, T.; Flouri, T.; Nichols, B.; Quince, C.; Mahé, F., VSEARCH: A versatile open source tool for metagenomics. PeerJ 2016, 2016, (10).

(10) Quast, C.; Pruesse, E.; Yilmaz, P.; Gerken, J.; Schweer, T.; Yarza, P.; Peplies, J.; Glöckner, F. O., The SILVA ribosomal RNA gene database project: Improved data processing and web-based tools. Nucleic Acids Research 2013, 41, (D1), D590-D596.

(11) Westcott, S. L.; Schloss, P. D., OptiClust, an improved method for assigning amplicon-based sequence data to operational taxonomic units. mSphere 2017, 2, (2).

(12) McMurdie, P. J.; Holmes, S., Phyloseq: An R package for reproducible interactive analysis and graphics of microbiome census data. PLoS ONE 2013, 8, (4), e61217.

(13) Gustafsson, J. P. Visual MINTEQ, 3.1; KTH, Dept Land \& Water Resources Engineering: Stockholm, 2013. 